Florida International University FIU Digital Commons

\title{
A Social Survey of Demography and Attitudes of Residents Regarding the Marine Protected Area in Puerto Morelos, Mexico
}

Alexis Roque
alexis.roque002@gmail.com

DOI: $10.25148 /$ etd.FI11120209

Follow this and additional works at: https://digitalcommons.fiu.edu/etd

\section{Recommended Citation}

Roque, Alexis, "A Social Survey of Demography and Attitudes of Residents Regarding the Marine Protected Area in Puerto Morelos, Mexico" (2011). FIU Electronic Theses and Dissertations. 480.

https://digitalcommons.fiu.edu/etd/480 


\section{FLORIDA INTERNATIONAL UNIVERSITY \\ Miami, Florida}

\section{A SOCIAL SURVEY OF DEMOGRAPHY AND ATTITUDES OF RESIDENTS REGARDING THE MARINE PROTECTED AREA IN PUERTO MORELOS, MEXICO}

A thesis submitted in partial fulfillment of the

requirements for the degree of

MASTER OF SCIENCE

in

ENVIRONMENTAL STUDIES

by

Alexis Roque

2011 
To: Dean Kenneth G. Furton

College of Arts and Sciences

This thesis, written by Alexis Roque, and entitled A Social Survey of Demography and Attitudes of Residents Regarding the Marine Protected Area in Puerto Morelos, Mexico, having been approved in respect to style and intellectual content, is referred to you for judgment.

We have read this thesis and recommend that it be approved.

$\begin{array}{r}\hline \text { Pallab Mozumder } \\ \hline \text { Ligia Collado-Vides } \\ \hline \text { Joel T. Heinen, Major Professor }\end{array}$

Date of Defense: November 2, 2011

The thesis of Alexis Roque is approved.

\begin{tabular}{r} 
Dean Kenneth G. Furton \\
College of Arts and Sciences \\
\hline Dean Lakshmi N. Reddi \\
University Graduate School
\end{tabular}

Florida International University, 2011 


\section{ACKNOWLEDGMENTS}

I would like to acknowledge and thank Dr. Joel T. Heinen, majoring professor, for the advice and guidance he has provided, as well as providing the opportunity to study in this field. I also want to thank the members of my committee for their support, assistance and suggestions, especially to Dr. Ligia Collado-Vides for her assistance and knowledge of the field site. The direction of my committee was most appreciated.

I offer my sincerest thanks to the Tinker Foundation, Inc. for their financial support. Thanks to their generous support, completion of the research at the field site was possible.

Major statistical analysis for the study was conducted and completed in conjunction with the Statistical Consulting Department of Florida International University, specifically, Andrea Roofe. I sincerely appreciate their support.

I would like to thank my family members for supporting me and encouraging me to pursue my dreams. Without their encouragement, I would not have completed this degree. 


\begin{abstract}
OF THE THESIS
A SOCIAL SURVEY OF DEMOGRAPHY AND ATTITUDES OF RESIDENTS REGARDING THE MARINE PROTECTED AREA IN PUERTO MORELOS, MEXICO

By
\end{abstract}

Alexis Roque

Florida International University, 2011

Miami, Florida

Professor Joel T. Heinen, Major Professor

This thesis research analyzed the perceptions of local community residents in Puerto Morelos, Mx., and its affect on the National Marine Park. Social and economic factors affecting the level of support for the marine park were evaluated. Formal semistructured written surveys were conducted with stakeholders in two major sub-regions affected by the protected zone. The survey allowed for comparison of stakeholders providing qualitative and quantitative information regarding attitudes, regulation awareness, and formation of the marine protected area. The results demonstrated a difference in knowledge level based on location in the community. Demographic indicators including education, nationality and community residency time are significant influences on the community perception of marine protection. There was a significant relationship between economic growth provided by the protected area and the level of support for protection resources. Further understanding of the relationship between social indicators and resource management is needed for conservation of important coastal resources. 
TABLE OF CONTENTS

CHAPTER

PAGE

INTRODUCTION

RESOURCE MANAGEMENT APPROACHES 4

SOCIAL IMPLICATIONS $\quad 10$

THE ROLE AND IMPORTANCE OF THE LOCAL COMMUNITY 14

PUERTO MORELOS, MEXICO: NATIONAL MARINE PARK 20

RESEARCH QUESTIONS AND HYPOTHESES 23

METHODS 25

STUDY AREA $\quad 25$

SURVEY DESCRIPTION 25

$\begin{array}{ll}\text { SAMPLING } & 27\end{array}$

RESULTS 28

KNOWLEDGE AND PERCEPTION BASED ON LOCATION OF RESIDENCE 31

DEMOGRAPHIC FACTORS AND PUBLIC PERCEPTION 31

THE RELATIONSHIP BETWEEN LOCAL SUPPORT AND ECONOMIC GROWTH 33

DISCUSSION 34

PLACE OF RESIDENCY INFLUENCING KNOWLEDGE AND PERCEPTION 36

THE IMPORTANCE OF DEMOGRAPHIC INDICATORS AND PUBLIC PERCEPTION 38

LOCAL SUPPORT WITH INCREASED ECONOMIC GROWTH 41

FUTURE SUGGESTIONS FOR MARINE CONSERVATION 42

$\begin{array}{ll}\text { REFERENCES } & 47\end{array}$

$\begin{array}{ll}\text { APPENDICES } & 52\end{array}$ 


\section{LIST OF TABLES}

TABLE

PAGE

1. Descriptive Statistics for Demographic Variables 57

2. Descriptive Statistics for Survey Questions 59

3. Chi-Square Analysis of Categorical Variables based 61 on Location

4. Hypothesis 1: Level of Knowledge and Perception 63 Based on Location of Residence - Mann-Whitney Test

5. Hypothesis 2: Demographic Indicators affecting

Public Perception \& Attitudes Towards Marine

Conservation - Logistic Regression Analysis Summary

6. Hypothesis 3: Local Support and Economic

Growth - Spearman's Rho 


\section{LIST OF FIGURES}

FIGURE

PAGE

1. Puerto Morelos National Marine Park Multiple use 68 zonation map

2. Information Deficit Linear Model Showing the Relationship between Social Factors and Variables with Environmental Behavior (Barr and Gilg, 2007)

3. The relationship between variables that structure the attitudes of households towards marine conservation in Puerto Morelos, Mexico (Sesabo et al., 2006)

4. Puerto Morelos, Quintana Roo, Mexico

5. Two Major Sub Regions of Puerto Morelos, Mexico: La Playa \& La Colonia

6. Average Age Of Participants Based Upon Location Of Residence

7. Average Number Of Adults \& Minors In The Household And The Average Total Number Of Individuals In A Household Based Upon Location Of Residence

8. Average Time (years) Head of Household has lived in Puerto Morelos, Mx. Based upon Location of Residence

9. Normal Distribution for the Logistic Regression Analysis of the Variable SUPPORTESTABLISHMENT

10. Normal Distribution for the Logistic Regression Analysis of the Variable INFAVOR

11. Normal Distribution for the Logistic Regression Analysis of the Variable OVERALL 


\section{INTRODUCTION}

In general, a marine protected area (MPA) is a near shore marine area set aside and managed for multiple objectives. Marine protected areas are used as key management tools for the security and conservation of biodiversity, along with the endorsement of sustainable marine resources that humans depend upon (Agardy et al., 2002; Bellwood et al., 2004). The ecosystem classification can also be incorporated into the ecosystembased management classification. This approach focuses on the whole ecosystem, including humans and our interaction with the system, with the overarching goal of maintaining a healthy productive system that continues human related services (Christie et al., 2009), and therefore integrating the ability to study and manage the resources of an entire ecosystem. That is to say, many organizational and national governments have conflicting views on the precise definition of an MPA, which may lead to confusion and ultimately a distraction from the main objectives of the protected area. Protected areas are put in place for conservation, resource utilization, traditional use, and sustainable use of a particular resource, which causes a conflict between groups and managers in determining overall operation. Each MPA is unique and faces its own form of environmental, social and socio-economic tribulations (Agardy et al., 2002), leaving today's managers and conservationists with the issue of finding an effective compromise between the best management strategy for marine ecosystems with the ability to preserve the ecosystems function and meeting the needs of individuals that depend on marine resources (Knowlton and Jackson, 2008). Marine reserves have been shown to aid in the conciliation by benefiting biota through protection and constituent users through food security, income from tourism, and pride in the protection of their surroundings (White et 
al., 2002; Hind et al., 2010; Tonioli and Agar, 2009). For example, the Town of Loreto in Baja California Sur, Mexico depends on fishing, both subsistence and commercial, for nutrition and income to the community (Stamieszkin et al., 2009). Marine reserves can also be connected into networks of small reserves to provide a higher level of biodiversity protection (Christie et al., 2009), provide a shorter distance for larvae to disperse, and protection from local disasters. However, these small-protected areas displace local fishing grounds and increase the level of non-compliance from fishermen, therefore increasing the fishing pressures within the reserve. In contrast, larger MPA's may be a better option for marine conservation. Larger MPA's cover more area and lower the social confusion of where fishing is or isn't allowed. This is one area where social science can be used to merge the idea of MPA utilizations for both biological protection and community dependency (Kritzer, 2004). Marine protected areas can therefore be used as successful management tools in conjunction with other tools, controlled by governments and environmental agencies, by balancing social and ecological goals (Christie et al., 2009). Local communities play a key role in marine protected areas management and their involvement improves the effectiveness of the protected areas. Generally speaking, the effectiveness of protected areas depends on the management action and policies instilled for the area along with evaluation of the management strategies to assess behaviors and promote an adaptive management approach (Camargo et al., 2009). The successes of a marine protected area are improved when local groups participate in the planning and decision making activities with government and nongovernmental organizations (Rodriquez, 2006). This presents a key issue in marine conservation and sustainability as to whether or not a MPAs failures and successes can be 
attributed to management's ability to incorporate stakeholders and the local community into their managing process (Hind et al., 2010).

Both the marine and terrestrial environment can be affected by natural and anthropogenic threats, altering the state of an ecological system. Marine areas have been seen as non-exclusive resources for multiple stakeholder groups (Camargo et al., 2009) in all parts of the globe. Threats to these systems and coastal resources can motivate the preservation, management and protection of these marine assets (Christie et al., 2009). Development, overexploitation of natural resources, habitat degradation through damaging fishing and harvesting methods, overpopulation of communities, political instability, poverty, and a countless other issues, all are dangers that exponentially change the state of ecosystems that are needed by local communities (Granek and Brown, 2005; Rodriquez-Martinez and Ortiz, 1999). For instance, development of local hotels in Puerto Morelos, Mexico causes a threat to the health of one of their most important resources; the coral reef system off shore. Development of hotels and resorts increases the nutrient and pollution levels of the coastal waters because sewage plants in the area are scarce, which results in waste circulating in mangroves and the surrounding waters. Recreational tourist activities and small fishing cooperatives can cause direct damage to coastal reefs as well (Rodriquez, 2006). Overfishing is of major concern in most MPAs primarily because of increasing human population and their dependency on the ocean for survival (Tissot et al., 2009). These extractions, along with countless others, inside marine protected areas create inconsistency at various levels and with different stakeholder groups. For example, destructive fishing methods cause rifts between the community and park authorities. Industrial-fishing groups within the area that are not subject to park 
regulations, controls, or penalties cause conflicts among residential fishermen, commercial fishermen and park managers. The disagreement between conservation goals and resource users, specifically the community, tourist, tourist operators and commercial fishermen, increase the threats posed to marine protected areas (Camargo et al., 2009). Overall, marine protected areas have important social and economic implications where the creation and expansion of reserves affect human utilization of the area and ultimately have a variety of social and economic outcomes. Marine Protected Areas are incorporating stakeholder groups into management plan and development more than before when reserves were based solely on ecological factors that leave out factors needed to accommodate human uses and needs. The marine reserve planning process includes both ecological and sociological factors in the beginning stages, to effectively implement a marine area (Cocklin et al., 1998; Mumby and Steneck, 2008; Florida Department of Environmental Protection, 2011).

\section{RESOURCE MANAGEMENT APPROACHES}

In light of all the benefits MPAs provide, it is easy to see that they are faced with many challenges leading the there implementation being a failure rather than a success. (Thur, 2010). Protected areas are more often than not created or proposed on the basis of biological information supporting protection to maintain the ecological components found in the system. Biological information is primarily collected to form a baseline to aide in the determination of managerial practices within marine reserves (Beger et al., 2005). However, better management is needed to alter human behavior, to focus more on conservation, and influence socio-ecological systems. Concentrations should be placed 
on ideal social approaches and how things should be administered rather than focusing on what is being done to accomplish management goals (Christie et al., 2009). Marine protected areas should have institutions, governmental and non-governmental organizations working together at various levels to fulfill social, economic and ecological objectives (Christie et al., 2009). The social dimensions of resource management can be important in promoting sustainability.

Community involvement is essential for the rules and regulations instated by managers to be effectively followed and enforced (Tissot et al., 2009). Communication and trust building are important features that must be established first in order to gain any level of support for marine conservation. The community, economic, and political system must work together to support conservation goals (Lundquist and Granek, 2005). The greater part of management strategies focus on regulating human activities in the protected area to minimize negative effects. However, a more effective approach may be to promote the positive human-park interactions by focusing on the most popular interests of the community (Jones, 2002). There are different management strategies that can be used to include the local community and stakeholder groups to further the success of a marine protected area (Jones, 2002). In general, top down approaches are government led and based on science where as bottom up approaches are community led and guided by science. Effective management lies between these two views in order to address all group concerns and the overall conservation efforts of the reserve (Jones, 2002).

Top-down approaches are known as centralized national models where the protection of the land and sea are established through IUCN categorization. These structures can be governed by a management board and individual sites are led by 
administrators that have the ultimate say in the decision making process. Top-down approaches will most likely have long-lasting effects but many times local decision makers are not considered in the management process and lack scientific research to base reserve implementations (Beger et al., 2005). In the Apo Islands, Philippines, community led management was initiated by the local university and invested most of their time in environmental education. In part, this changed the perceptions and views of the local people to a more conservation-based mind-set, which led to sustainable management of the protected area. Management was then transferred from community-based organization to the centralized government approach, because of the fear of local communities exploiting marine protected areas for economic benefit. The national based management created the feeling of alienation and disempowerment of the people who needed the area to maintain their quality of life. Abrupt changes in management lead to rebellions where residents violate rules and regulations set forth by the park. For MPAs to be successful, legislation needs to implement sharing of decision-making powers between national, state, and local entities (Hind et al., 2010). Coastal management that is against the community and does not include their support leads to the failure of the area and its ultimate conservation goals (Beger et al., 2005).

In contrast, bottom-up management structures are highly recommended in most marine areas and focus on having the local community involved in the selection of the MPA boundaries from an early stage (Jones, 2002). Most successful MPA's are those where locals express an interest in protecting and conserving their natural resources. More stakeholders are now being included into the decision-making and implementation process, which can both benefit and challenge the design of a reserve. The amount of 
involvement varies between groups, but the inclusion of diverse groups is needed in park planning. Local community residents are an influential group that should be included in the planning, designing, establishment and management of an area because of the level of support and assistance they need to provide to maintain the area. Inclusion provides locals with a sense of ownership and commitment to the marine area and promotes longterm interest in protection. Loreto Bay National Park in Baja California Sur, Mexico was established after a number of local community members, scientist, tourist, and conservationist in the community petitioned to have their local resources protected from further deterioration caused by anthropogenic effects (Stamieszkin et al., 2009). Marine protected areas in Papua, New Guinea, involved multiple groups and community members, which aided in the effortless acceptance and enforcement of the area by the residents (Lundquist and Granek, 2005).

Co-management approaches join together top-down and bottom-up management techniques, which focuses on combining both national jurisdiction and local community control. Co-management can lead to the empowerment of local people to take part in the natural resource management of the system through self-governance and conservation education. The management strategy can also help mitigate social issues and address biodiversity concerns affecting conservation efforts. Co-management integrates education and local knowledge, which can fill scientific knowledge gaps that ecological indicators cannot obtain (Granek and Brown, 2005). Conversely, co-management can have its disadvantages. Limited scientific knowledge and government resources affect the design of marine protection and the overall success of the park. Political and economic issues are deemed more important and override conservation concerns. Co-management should not 
replace scientific data used to implement a reserve and should not be used as a sole means of protection in the absence of scientific, political and socio-economic issues, although it can be used to incorporate local knowledge into management methods that lack scientific data. Co-management is an important management method in that it can be used as a model for other conservation objectives. Co-management leads to communityled monitoring programs along with basic scientific data collection methods that may attract important institutions and scientists to conduct research in areas that promote and benefit the community (Granek and Brown, 2005).

Co-management can be divided into three levels: Consultative, Collaborative, and Delegated. Consultative co-management involves the government interacting with stakeholders, but ultimately making all management decisions. Collaborative comanagement focuses on the government and stakeholder groups working together to reach conservation efforts and sharing in the decision-making duties. In Delegated comanagement, the government allows for formally organized stakeholders to make decisions, in which the people who live and work in the area take an active role in the planning, enforcement and decision making process. Delegated management structures are uncommon and rarely seen in developing countries (Granek and Brown, 2005; Rodriquez, 2006; Sale et al., 2005). Increasing the ability to plan and negotiate with stakeholders represents the needs of these groups. In turn, the management determines the different levels of government that can create agreements between conflicting groups, as well as defining the roles of each unit that can increase the effectiveness of marine protected areas. Engaging in adaptive management practices can enhance the communities' ability to co-manage its resources through environmental education 
(Rodriquez, 2006). Adaptive Management is most effective when scientist, managers and the local community work together and communicate well, therefore building political will, developing connections and collaborations as well as providing opportunities for funding (Sale et al., 2005). Early establishment of co-management for marine ecosystems makes them more successful, as seen in the management approaches in the Philippines. Fishermen noticed an increase in fish abundance after the protection and maintenance of coral reef habitats for biodiversity and multiple economic uses. The localized management system had more support by national and local governments, which increased local motivation to protect the area and provided locals with a sense of ownership (White et al., 2002).

Other management approaches include traditional reef management and traditional fisheries management, which are geared towards protection through cultural and religious practices that indirectly promote the health of a system (Cinner, et al., 2005). Designing and managing a protected area through cultural values provides an incentive for locals to conserve their wildlife. Societies have different perceptions of nature and vary in the spiritual value that ecological areas provide. Traditional management allows for the development of protected areas to be flexible and easily managed. It provides an effective way to reach conservation goals and for governments to justify the support of protected areas to various communities (Infield, 2001). Indigenous cultures have been practicing marine resource management before the implementation from western cultures by using limited entry, closed seasons and areas, size limitations for catch, and gear restrictions. Many villages are adapting these traditional marine resource practices to comply with changing ecological circumstances (Johannes, 2002). 
Bylaws, or village regulations that are given legal recognition, can help in the preservation efforts and reduce resistance to the establishment of protected areas. These laws need to be adjustable to meet the changing state of the resources and systems. The more problems arise, the more they need to be included into the management plan (Johannes, 2002).

Over the past few years, changes in management regimes had to be made to adapt to local perceptions of how marine resources are decreasing along with creating alternative forms of income that can be earned by keeping these coastal areas healthy (Johannes, 2002). Traditional management strategies in conjunction with co-management approaches may be one of the best methods for areas that have limited resource protection available (Knowlton and Jackson, 2008). Managing human involvement and activity for better coral reef system health depends on the aforementioned conflict between MPA size, establishment and location (Bellwood et al., 2004). Pride among indigenous groups is growing and the connection between people and the sea is becoming more important through intrinsic values in their natural resource management. Changes in management are also because of political independence of many islands with surrounding marine reserves. These factors play a key role in their ability to establish legislation by granting authority to traditional leaders and by reinstating customary laws and practices (Johannes, 2002).

\section{SOCIAL IMPLICATIONS}

In developing countries, programs are created and included into management plans to encourage consistent support and continued environmental action by local citizens. The overall goal of protection is to reach a specific target by encouraging 
participation from local community members in environmental behaviors that reduce the negative impacts on the environment (Barr and Gilg, 2007). To promote a positive mentality of environmental action from locals, a better understanding is needed on the factors that influence an individual's decision-making process. Different factors influence environmental actions. These include situational variables, psychological variables, and social/environmental variables (Barr and Gilg, 2007). Individuals can be influenced to act positively towards the environment when there is a perceived threat or danger to their environmental resources, as well as supporting environmental decisions made by trusted institutions providing scientific information (Baldassare and Katz 1992; Sguin et al. 1998; Nancarrow et al 1995-1997; Mainieri et al 1997). Friends and family play an important role by being a key component influencing an individual's behavior. Positive environmental behavior would more likely be seen when a community member witnessed friends and family practicing environmentally sound behaviors (Sadalla and Krull 1995; Lam 1999). Intrinsic motives are those environmental behaviors that are done under the notion that it will bring some sort of satisfaction from helping the environment. This is more generally known as the attitudinal concept focusing on factors that affect behavior (De Young, 1986; De Young, 1996). Response Efficacy is another concept describing the behavior of an individual having an impact on the environment and the need to inform individuals of their control on their local resources (Samuel-son and Biek 1991; Roberts 1996). One of the biggest arguments towards getting the best form of environmental action is through knowledge. Knowledge is an important variable that affects the level of environmental engagement (Barr and Gilg, 2007). Studies have determined that environmental commitment was influenced by social values relating to ecological 
practices (Stern et al., 1995; Cameron et al. 1998; Corraliza and Berrenguer 2000). Studies focusing on behavior and what controls environmental contribution can be used to determine what type of policies should be made to mold the behavior of a community to one that is conservation oriented (Barr and Gilg, 2007).

Socioeconomic factors and perspectives on management are important when creating conservation policies. These are essential in effective enforcement systems, gaining local community support, and earning the respect needed for established regulations (Broad and Sanchirico, 2008; Bellwood et al., 2004). Evaluations of reserve and indicator effectiveness can determine if an MPA is achieving its objectives. If the reserve is failing, the problems need to be detected to remove the possibility of a "false sense of security" among the community that their resources are being protected (Jones, 2002). Christie, et al., (2002) reviewed the management abilities of two small marine reserves off the coast of Balicasag island and Pamilacan island in the Philippines. The community lacked organization, education and local leadership, which may be a result of the reserve's lack of enforcement, isolation and a reduction in overall benefits to the community. In this case, the benefits of the reserve were going to outsiders rather than to individuals who were suffering the direct cost of having an MPA in their vicinity, therefore leading to more violations. Acknowledging the different social processes helps in determining the success level of a marine protected area (Murray, 2005). Factors including awareness of objectives and rules, dependency on coastal resources, and socioeconomic conditions, can be used as indicators to understand their role in park success. Household behaviors and attitudes towards natural resource management depends on demographics and socio-economic factors, which creates varying levels of 
support affected by the costs and the benefits of living near a protected area (Sesabo et al., 2006). Some socio-economic factors include: dependency on and use of coastal resources, length of residency in the area, perception of what can affect and improve fishery resources, coastal resource governance practices, compliance with governance practices, etc., which can all be obtained through social surveys (Cinner, et al., 2005). Community and stakeholder analyses help determine the interests of groups and their capability to contribute to the management system. Similarly, multi-stakeholder models are used in different management scenarios to help with an organizations inability to provide all the resources to run a park. These models introduces an incentive system to distribute the costs, benefits, rights and responsibilities among community members and is only found in co-management and community based management strategies. For example, promoting user fees for divers is one way to have those that benefit from marine protection "pay" for the cost that other groups must incur by having a reserve in their surrounding areas. Some stakeholder groups are also more influential to the public's decisions and perceptions through their high levels of social, economic, and political power (Tongson and Cola, 2007). Consideration of different economic niches allows for managers to adapt their plans and strategies towards protecting more of the marine area needed for different forms of income, rather than focusing on just one livelihood, like fisheries. Being able to identify the perceived attitudes of community members can be an effective tool to better understand why and how the community recognizes the need for resource conservation (Sesabo et al., 2006). In a study done by Suman, et al. (1999), the perceptions and attitudes of stakeholder groups towards marine reserves, specifically Florida Keys National Marine Sanctuary, were determined through surveys to understand 
the social and economic interest of different user groups, along with determining what obstacles managers face when working with these groups. Overall, the fishermen felt alienated from the zonation planning that was implemented and dive operator groups participated the most in the process, but still expressed concerns on the limitations of the zoning (Suman, et al., 1999). Social processes influence MPAs and traditional reef closures, which may have conservation benefits for marine ecosystems (Cinner, et al., 2005).

\section{THE ROLE AND IMPORTANCE OF THE LOCAL COMMUNITY}

The need for communication and education of locals and visitors is essential to a successful marine park. Education of the community is important and can be reached through formal and informal educational programs and public awareness campaigns that influence individuals to make informed decisions (Beger, et al., 2005; RodriquezMartinez and Ortiz, 1999). These programs enhance the conservation experience and improve the diffusion of biological information. Particularly, the programs lead to behavioral changes and ultimately alter attitudes towards marine protection (RodriquezMartinez and Ortiz, 1999). Stamieszkin et al., (2009) determined educational and information campaigns as positive methods to increase the compliance of park regulations with young adults in the Loreto Bay Marine Park of Baja California Sur, Mexico promoting conservation of natural resources and local ecosystems. They noted a relationship between increasing education towards marine conservation and the compliance of park regulations because of a better understanding of why these rulings are needed. The level of dependency on marine resources varies between location and is directly related to the population size and socioeconomic status of the community, 
therefore intensifying the need for better resource management to prevent overexploitation of supplies (Beger et al., 2005). Effective policy can be developed on the basis of these variables to include most perspectives and socioeconomic conditions. The local perspectives of individuals in a Bahamian community were documented through surveys in Broad and Sanchirico's (2008) study to demonstrate the relationship between socioeconomic status and MPA support. Researchers compared five different neighborhoods in the Bahamas and how their socioeconomic status related to their level of marine support. Those that considered the environment to be in poor condition had considerably higher income and were dependent on tourism for their source of revenue. This group supported the creation of a reserve. On the other hand, those that saw global pollution as the major threat to their area, believed that current management was in good standing and were reliant on fishing for their livelihood, therefore less likely to support the creation of a reserve. Inclusion of the local community builds confidence in the people to manage their own resources and encourages long-term sustainability. For example, MPA's in the Philippines have Local government codes that decentralize the task of running an MPA to local governments, providing more power, authority and responsibility to the local villagers. Consequently, there are currently no legislative standards in the Philippines for the local government and the community to follow for management of a marine area, or for the inclusion of social factors into local government plans (White et al., 2002). Educational programs can be hands-on by involving the community in research and monitoring programs on a volunteer basis, which alleviate financial support issues and increases awareness. 
Sampling various groups and identifying their opinions towards marine reserves can easily determine the wants and needs of the community. The opinions are closely associated with their socio-economic status. Decision makers and managers need to better understand the socio-economic impacts of park regulations and should integrate the knowledge of these groups into the management process (Tonioli and Agar, 2009). Prevention of negative attitudes towards marine reserve creation occurs by enhancing public relations and creating marine protected areas based on the needs of each specific village, which depends on socio-economic variability and demographics (Heinen and Shrivastava, 2009). In Moheli, Comoros Islands off the coast of Africa, co-management approaches were created with local communities because of the regional governments inefficiently addressing a number of important issues. Inhabitants became responsible for monitoring and enforcing the park and were included in the decision making process for creating park guidelines. Local community workshops were also administered to increase the knowledge and awareness of marine ecology to Comoros Island locals to build interest, involvement, and environmental literacy (Granek and Brown, 2005). Similarly, in the Southern Caribbean, stakeholders and community members view their marine resources, including corals, mangroves and beaches, as highly important and express a level of interest in conserving the areas for future generations. Villagers understood that co-management is a combination of external regulations and the internal ability to participate in making management decisions for the protected area. Community-based management in this example is easily adaptable for communities to follow than nationally implemented law, because of the combination of strategies with public and social investments, including structure and alternative forms of income, that all enhance reserve 
performance. Likewise, it provides opportunities to improve governability and the quality of life of the area (Camargo et al., 2009). A similar theme was seen in First Nations, particularly local communities of Canada, where members of the community expressed an interest in fishery protection for present and future generations (Ban, et al., 2008). Securing improved living standards and livelihood for communities directly relates to their use of the resources in and around the reserve. Resource use should be included in the management agenda of authorities and reinforced by the capacity to increase a groups understanding of the social importance of these reserves (Camargo et al., 2009). Social attitudes and perceptions regarding marine reserves should be monitored to assess the effectiveness of the parks objectives in satisfying the concerns of the stakeholders. One way to compensate for the socio-economic factors being compromised is to allow local residents to decide on the location of a marine protected area. Scientists can determine the principles relevant to the society and explain the benefits to the people. They can also aide in the determination of where the MPA should be established in conjunction with the local community. Determining the location can also provide insight into the social impacts that benefit establishments of marine reserves (Cocklin et al., 1998). In Tanzania, compliance with local MPA's and the level of knowledge in coastal communities, limits management. More knowledge of the area leads to an increase in compliance of conservation initiatives. Conservation and management strategies are created and altered in this area to gain the support and participation of the people. The socio-economic status of the villagers relates directly to the effectiveness of the reserve. Poverty, lack of education and an understanding of resource management, play a role in the success of the reserve and affects the livelihood of the coastal community. Most of 
the communities in this area are poverty-stricken and relying on coastal and marine resources is not enough for economic support, making it difficult to establish conservation efforts. Although, establishment of an MPA can provide other activities for economic support that do not rely on consumptive uses. Determining the villages' initial perception on creating a reserve is important to help with conflict resolution (Sesabo et al., 2006). In addition, Sesabo et al. (2006) found that villagers in Tanzania were generally in favor of one reserve because of the creation of jobs and the ecological, social and recreational benefits it provided. Those that opposed its creation believed that poor households would suffer the economic cost of the reserve because of access restrictions and social cost brought on by the protection. By presenting some level of benefit to the community, the majority of the members accepted the creation of the reserve and this led to long-term support.

Compliance with community-based protection is essential because of the low levels of enforcement seen with most marine protected areas. If community members know that the degree to which they can get caught for illegal park activity is high, the levels of noncompliance are reduced. Non-compliance can also be reduced through education, outreach, and inclusion into the process (Kritzer, 2004). Encouraging locals to become part of the conservation efforts is possible by making an economic link between local communities and the protected area (Infield, 2001). In the Apo Island, Philippines, a study was conducted to analyze the differences between the livelihoods of diverse village populations on the island. Islanders, key informants, and elders were all surveyed and expressed a similar theme of exclusion from management decisions and had a sense of disempowerment by the national government. In this case, the centralized management 
approach does not consider the opinions of the villagers. For instance, islanders were against the creation of vacation homes in front of the MPA and expressed their concerns on the development project, however the task continued without consideration of villagers opinions. Those interviewed felt that alternative forms of economic stability were not present and the current revenue collected was not being redirected into maintenance of the park. The previous management structure was more effective by providing villagers with a higher quality of life and setting up most of the environmental protection plans currently in place. Co-management was highly favorable among locals, with a combination of community led management and centralized national administration, because they felt that their opinions were better accounted for (Hind et al., 2010). Domestically, Hawaii's community expressed a strong interest in local comanagement of marine resources. Community based continuation fishing areas were created that allowed communities to help in the development of enforcement regulations and procedures. The goals of this area were set and reached by involving the community into the process, promoting sustainability of marine resources, and reducing user conflicts over resources. The presence of both management approaches allowed for legislation to be effective and demonstrates successful MPA management (Tissot et al., 2009). Social Networking is important and can be used to influence the attitudes of local communities towards marine protection. Local communities may be driven to protect their resources based on cultural values to maintain social relationships with neighboring clans (Kritzer, 2004; Cinner et al., 2005), therefore being influenced by societal associations to favor protection. More connections with surrounding villages and community members means 
an increase in sharing of information between peers, which can affect the positive environmental attitude needed to gain support (Sesabo et al., 2006).

\section{PUERTO MORELOS, MEXICO: NATIONAL MARINE PARK}

As noted before, marine protected areas are successful and can be improved when local stakeholders participate in the planning and decision making activities of the area in conjunction with the government. Quintana Roo is the largest tourist destination in Mexico and more than half of the native population of the state lives in the northern portion along the coastline, from Cancun to Tulum. These high population levels and increases in tourism have led to overexploitation of coastal resources and ecosystems including coral reefs, sea grass beds, mangroves and beaches. Aside from the most common sources of ecosystem damage, the lack of proper environmental education in Mexico, especially Quintana Roo, for all groups can now be considered one of the major causes of marine ecosystem damage (Rodriquez-Martinez and Ortiz, 1999). In Puerto Morelos, the neighboring reef was originally protected through a community-based approach of local stakeholders assuming responsibility for the management program. The reef was originally denied protection when the national government did not view the area as an important economic zone and funding of the protected area would be difficult to maintain. The local community was able to change the outlook of the national government by working together to fulfill the requirements requested by the government and providing scientific information about the reef. Fulfilling the requirements validates how the community participation process initiated by locals can overcome national government opposition (Rodriquez, 2006). Protection of their natural resources and tourism that coincided with conservation efforts were needed in the area and could be 
assessed through extensive socio-economic and ecological analysis of the village. Those affected by the creation of the park were resistant to the growth of development because of their perception of the importance of the surrounding mangroves. Villagers also feared that too many tourists would enter the MPA because of the proximity to Cancun (Murray, 2005). The management program promotes community participation through the establishment of a sustainable development program focusing on actively involving locals in the conservation of their resources and providing benefits to the community. Participation, in this example, is a result of the interest and awareness of the community's dependency on the reef, the threats of coastal development, inefficiency of the government to protect the resources without community support, and the knowledge of how important the MPA is to preserve the quality of life in municipality. The community was included into the MPA establishment before, during and after, which gave the locals a sense of possession to the park and a drive to protect it (Rodriquez, 2006). The management strategy in Puerto Morelos is a good example of the local people being able to control how quickly and how much the town changes as a result of tourism. Inclusion of the community played a major role in the development of the management plan and without their contributions the protection would not be in place today (Murray, 2005). Although, education and public awareness programs about coral reef ecosystems began in Quintana Roo with the sudden increase of the tourism industry in the 1970's, shifting the focus to visitors rather than locals (Rodriquez-Martinez and Ortiz, 1999). Continued education of the public on the importance of coral reefs and their protection is crucial to their long-term survival. In a study done by Rodriquez-Martinez and Ortiz (1999), six coastal communities, where coral reefs are an important resource for livelihoods, took 
part in an educational program of elementary, secondary and high school students, including students in Puerto Morelos. The program was used to educate the students on coral reef ecosystems as well as assess their awareness. The overall results of the Rodriquez-Martinez and Ortiz study (1999) showed a lack of awareness across all six communities with less than $50 \%$ of the students ever visiting a coral reef. The disparity found between communities that participated in the study were a result of demographics, resource accessibility, the start of the educational program, and socioeconomic status of the students. Rodriquez-Martinez and Ortiz determined that of the 383 Puerto Morelos students in the study, $42 \%$ visited the reef, which is a result of the easy accessibility of the reef from the beach, students being apart of fishermen families, and possibly having tour guide family members. Students in Puerto Morelos live closer to their marine environments in comparison to other communities in the study, like Cancun, where transportation would be needed to see the reefs. The researchers also determined that the coral reefs are used for recreational activities and are commonly discussed in the town. Moreover, There are few educational programs in Puerto Morelos because of little funding opportunities and personnel; therefore the education on coral reefs is currently reaching a small number of students through non-governmental organizations and education departments of tourist parks that have developed environmental education programs.

Puerto Morelos National Marine Park is located off the coast of Puerto Morelos, Quintana Roo Mexico; a small fishing village located on the Northeast Coast of the Yucatan Peninsula, $30 \mathrm{Km}$ south of Cancun. The Mexican Government deemed the MPA a National Park, IUCN category II, in 1998, after local community members 
articulated an interest in protecting their natural resources, as previously described above. IUCN Category II protection safeguards areas that are large and set aside to protect ecological processes and species that provide a foundation for scientific, recreational, $\begin{array}{llll}\text { educational uses, } & \text { and } & \text { including } & \text { tourism }\end{array}$ (http://www.iucn.org/about/work/programmes/pa/pa_products/wcpa_categories/pa_categ oryii/, 2010). The National Park is approximately 9,066 hectares divided into multiple use zones satisfying the many needs of locals and visitors (Figure 1). Puerto Morelos National Park has multiple objectives and goals for the protection and sustainable use of the natural resources the park provides. The management plans and objectives focus on species and ecosystem protection, recreational and tourism uses, restoration of degraded reefs, and local and visitor education (http://cep.unep.org/caribbeanmpa/mpa/puertomorelos/?searchterm).

\section{RESEARCH QUESTIONS AND HYPOTHESES}

The overarching goals of this research are: 1) To determine the perceptions and views of local communities in Puerto Morelos 2) Determine the community's perception of how their lives have been changed since the establishment of the National Marine Park and 3) To assess the social and economic factors affecting the level of support for the marine protected area. These goals were reached by addressing three main research questions: 1) what is the basic level of knowledge of local residents about the marine protected area?, 2) Is there a significant difference between residents living in different communities in their level of knowledge, awareness and perception?, and 3) What specific demographic indicators influence the attitudes and levels of perception of the local residents towards the marine park? 
Specific objectives to answer the research questions above include: 1) Assess residents' opinions and knowledge of the area and its regulations, 2) Determine the attitudes and awareness of Puerto Morelos residents, and residents of other nearby communities, toward the park, 3) Determine the advantages and disadvantages, based on residents' perceptions, of having and MPA in this location, 4) Provide information and to local officials for aid in improvement of the MPA management and community involvement, and 5) assess the relationship between demographic indicators and the perceptions of local residents. In order to evaluate the above research activities, the following hypotheses have been suggested: 1) Residents living in communities closest to the MPA will have a higher understanding, higher level of knowledge and more positive perceptions of the area, 2) Demographics and socio-economic status of local residents are an important predictor of the perceptions towards the marine park, and 3) Local residents will provide more support for marine protection as opportunities for economic benefits increase. The Information Deficit Linear Model (Barr and Gilg, 2007) was adapted to fit the workings of this research (Figure 2). A conceptual model referring to the relationship between factors that structure the attitudes of households toward marine conservation used by Sesabo et al., (2000), was adapted for this study to aide in determining what social factors affect attitudes and awareness of local residents in Puerto Morelos, Mexico (Figure 3). The main idea here is that values and behaviors are linked and interact with other situational and psychological factors, previously discussed, to lead to an intention and ultimately a final behavior (Barr and Gilg, 2007). Presenting the benefits of marine protection to the community is vital in gaining their support. Biological indicators and the beneficial factors of marine protection is at its greatest when it is translated to a "common 
language" that the public can understand (Doren et al., 2009). My research has the potential to provide extended input for the park authority in Puerto Morelos to increase support for the protection of the marine protected area. The results of this study can further encourage the use of adaptive management approaches to include better education and increase awareness of the area as more information is discovered. Adaptive management approaches can be used to actively monitor and control human activity that can negatively alter an ecosystem (Bellwood et al., 2004). It will facilitate the creation of other such studies focused on promoting the benefits of protecting the local communities natural resources.

\section{METHODS}

\section{STUDY AREA}

The study was conducted in Puerto Morelos, Quintana Roo, Mexico (20 51'13'N and $86^{\circ} 53^{\prime} 55^{\prime} \mathrm{W}$ ) from July 1 to July 30,2010 . The small fishing village is located on the north east coast of the Yucatan Peninsula of Mexico. It is approximately $42 \mathrm{~km}$ south of Cancun, and $36 \mathrm{~km}$ north of Playa Del Carmen, Quintana Roo, Mexico (Figure 4). Residents from two distinct parts of Puerto Morelos were interviewed. One part is located along the beach side and the second is located adjacent to the local mangrove ecosystem approximately 1 mile inland (Figure 5). The former is referred to as "La Playa" and the latter, "La Colonia."

\section{SURVEY DESCRIPTION}

Formal semi-structured written surveys were conducted with stakeholders affected in Spanish (Appendix 1). Stakeholders interviewed included: local residents, members of organizational groups, fishermen, tourism operators, and local merchants. 
Fixed answer questions made up the majority of the survey to allow for statistical comparison between and within stakeholder groups. The survey also included some openended questions to allow for further details or issues to be obtained from participants. The first page was divided into two sections. The first section of the survey focused on the demographics of the participants to allow for comparisons between the demographic indicators and the locals perceptions and knowledge. The second part of the survey consisted of questions focused on determining what the partakers knew in regards to the park regulations and rules, as well as their opinions on the park enforcement. The second page focuses on the resident's opinions and knowledge of the area which helps reach the research objectives. It also focuses on establishing the advantages and disadvantages of living near a marine protected area, based on their perceptions. The last page of the survey concentrated on assessing the resident's general knowledge of marine protection and how effective conservation is. The assessment will provide us with an overall idea of what residents know. The knowledge and understanding portion of the survey together with the opinions portion can help determine what the overall attitude of the community is towards the marine protected area. These evaluations will provide both qualitative and quantitative information regarding attitudes and awareness towards policies, rules, regulations, and the formation of the marine protected area. The draft survey was pretested in 2009 by Dr. Joel T. Heinen of Florida International University, in and around Puerto Morelos. The survey was updated based on the pre-test and was ready to implement at the time of the study. 


\section{SAMPLING}

The local community has approximately 6,000 households. A 5\% sample size of the population was interviewed, or 300 separate head of household surveys. Surveys were conducted in both "La Colonia" and "La Playa" town centers as well as in residential areas on both sides. Ninety surveys were conducted of La Playa residents and 209 were conducted of La Colonia residents, which is the approximate portion of the population that each part of the town represents. The residential area included households along the beach, two gated communities, and residential neighborhoods west of "La Colonia" Town Square. The local fishing neighborhood where fishermen and their families live is known as "La Colonia de los Pescadores" or Fishermen's colony. The Fishermen's Colony area was deliberately left out because the fishermen stakeholder group was surveyed by conducting the interviews along the pier on the beachside where the fishing cooperative is located. The surveys were reviewed and analyzed to obtain descriptive statistics for basic comparison of questions. Basic descriptive statistics were calculated to summarize the data set. A Mann-Whitney test was performed to determine if there was a significant difference between the level of knowledge and perception of residents living in either side of the community. A logistic regression analysis was completed to determine the importance of demographic indicators on the resident's knowledge and perception of marine protection. Lastly, a Nonparametric Pearson Correlation analysis was computed to evaluate the relationship between local support and the opportunity for economic growth of the community. A small number of residents, approximately 1 in 5 individuals, rejected to take the survey. 


\section{RESULTS}

Table 1 presents the descriptive statistics of demographic indicators of participating residents. Although the dataset was considered one population, the population was divided into two subpopulations for comparison. The majority of the participants (69.7\%) resided in La Colonia. The respondents were primarily male (65\%) between the ages of 15-68, with the average age of the Household Head being 33.58 years and a median age value of 31.00. The household size ranged from 1 individual to 14 individuals, with the median value being 4 . The average and median number of minors under the age of 18 was 1 . There was an average of 3 adult household members with a median value of 2 adults. The level of education for the household head was fairly distributed between fundamental education with Elementary education being the most common (27.9\%) and Middle School and High School following (26.6\% and 24.6\%, respectively). Higher levels of education were less common with $12.1 \%$ of the respondents at the college level and about $8.8 \%$ have University Degrees. The average time period participants lived in Puerto Morelos, Mexico was 14.46 years with a standard deviation of 12.08. The data collected for the origin of birth of the respondents were grouped into three categories: 'Born in Mexico', 'Born in Yucatan Peninsula of Mexico', and 'Born outside of Mexico'. 'Born in Mexico' refers to other cities of the country that were not found within the Yucatán Peninsula and 'Born Outside of Mexico' refers to other countries of origin. The majority of the individuals were from the Yucatan Peninsula (58.0\%) with $32.3 \%$ of the participants being from other parts of Mexico, and 9.7\% from other countries. About one fifth (19.3\%) of the participants were born in 
Puerto Morelos, Mexico. The most common occupation was within the Restaurant and Food Service Industry as well as the Skilled Labor sector (18.3\%).

Table 2 illustrates the descriptive statistics performed on questions in relation to marine protected areas. The overall population was fairly aware that a marine protected area was in their local vicinity $(54.7 \%)$, but a large portion of the participants were unaware that there was a form of protection in their municipality (45.3\%). A small percentage of respondents agreed that their livelihood was dependent on the MPA $(31.7 \%)$ and small percentage $(12.7 \%)$ is employed through park. More than half were unaware of the rules and regulations of the MPA (60\%) and those who were informed of the park rules $(40 \%)$ learned from experience $(16 \%)$ or were unsure as to how they know the rules and regulations $(61.7 \%)$. Of those who knew the rules, $32.2 \%$ agreed with all the regulations while $9.7 \%$ agreed with only some of them. The rest of the participants disagreed with the rules of the park or were unsure what the regulations were. The majority of households did not know any park personnel $(63.7 \%)$ but most of the respondents supported the establishment of the marine park (55\%). A small portion of the participants admitted to receiving a citation for violating a park regulation $(8.7 \%)$. For questions that were on a four-point scale similar to that of the likert scale (agree, disagree, neutral, do not know), most responses were 'do not know.' Questions relate to park management, efficiency of the management plan, increases in marine protection for critical species or habitat types, tourism management, and the overall creation of the marine protected area (Table 2).

Chi-square analyses were conducted on categorical variables to test the significance and independence of each variable from location of residence; La Playa $(\mathrm{n}=$ 
91) or La Colonia $(\mathrm{n}=209)$. Table 3 summarizes the results of the chi-square analysis for each variable. The goodness-of-fit test showed a majority of the variables being independent and differing significantly by location, with a significance value of .05 . The only variables from the survey that did not differ significantly from dependency on location of residence were GENDER $(\mathrm{p}$-value $=0.060)$, DEPENDENT $(\mathrm{p}$-value $=0.390)$, CITATION $(\mathrm{p}$-value $=0.066)$, and CREATION $(\mathrm{p}$-value $=0.107)$. Figures $6-8$ depict the results of the descriptive continuous variables found in table 1 and analyzed on the basis of location of residence. In figure 6, the average age of participants living in La Playa was slightly higher (35.49 years) than individuals who resided in La Colonia (32.75 years). The youngest participant in La Playa was 15 with the oldest being 65. La Colonia had similar results with the minimum age being 16 and the oldest being 68 . The median age value for La Playa was 35 and 29 in La Colonia. In relation to the number of individuals living in a household, figure 7 shows that the average number of adults (Playa $=2.41$ vs. Colonia $=3.00)$ and children under the age of $18($ Playa $=1.15$ vs. Colonia $=$ 1.41) living in a household was approximately the same for both neighborhoods. The maximum number of adults living in a household in La Playa was approximately 8 and the minimum being 1. La Colonia showed similar results with the maximum number of adults living in a household being 10 and the minimum being 1 . The average total number of family members residing in a home was slightly different with approximately 4 in La Playa and 5 individuals in La Colonia. La Playa had a minimum of 1 individual in the household and maximum of 10 total individuals in the household compared to $\mathrm{La}$ Colonia that had a minimum of 1 individual in the household and a maximum of 14 total household members. Figure 8 shows individuals participating in the study that resided in 
La Colonia lived in Puerto Morelos approximately two years more (15.17 years) than individuals who were residing in La Playa (12.84 years). Both La Colonia and La Playa had the same minimum value for residency in Puerto Morelos (1 year). La Colonia also had a higher maximum value for residing in Puerto Morelos (68 years) when compared to La Playa (45 years).

\section{KNOWLEDGE AND PERCEPTION BASED ON LOCATION OF RESIDENCE}

A Mann-Whitney test concluded that a significantly higher level of education was determined for La Playa compared with La Colonia (Mann-Whitney, $\mathrm{p}=0.05$; Table 4). For the variables GENDER and EDUCATION, both demographic indicators, La Playa had the highest mean rank suggesting that participants in this location had higher education scores as well as differences in knowledge level between genders. La Playa also had higher mean ranks for the variables of CREATION, JOBOPPORTUNITIES, PROFESSIONAL, MPAMANAGEMENT, EXPERIENCE, CORAL, FISH SEAGRASS, ADEQUATERULES, TOURISM and OVERALL. The Mann-Whitney test showed a statistically significant difference between participants residing in La Playa and those residing in La Colonia for all variables except, GENDER $(U=8437.0$, p-value $=$ 0.060), DEPENDENT $(U=9032.0, \mathrm{p}$-value $=0.391)$, CITATION $(U=8892.5, \mathrm{p}$-value $=$ $0.067)$, and FISH $(U=8529.5$, $\mathrm{p}$-value $=0.106)$. There was no significant difference between the neighborhoods with these variables.

\section{DEMOGRAPHIC FACTORS AND PUBLIC PERCEPTION}

A logistic regression analysis concluded that the demographic variables describing educational level, nationality, and average time of residency in Puerto Morelos 
are a significant influence on the positive perception towards marine protection (Logistic Regression, $\mathrm{p}=0.05$; Table 5). The variable SUPPORTESTABLISHMENT looked at the respondents support for the creation of the park by agreeing or disagreeing with its creation. The responses to SUPPORTESTABLISHMENT were fairly even where 55\% of the participants agree with the creation of the marine protected area, compared to the $45 \%$ who disagreed or did not know. The variable INFAVOR evaluated the respondent's satisfaction and support of the rules and regulations of the park. Responses for the variable INFAVOR were primarily not in favor of the rules and regulations (58\%) and $32.3 \%$ responded yes to be completely in favor of all the rules and regulations. Only $9.7 \%$ of participants responded to being in favor of some of the rules, but not all. Combining both 'yes' responses into one category, the results change to $42 \%$ responding yes and 58\% responding no. The variable OVERALL looked at the participants overall satisfaction with the creation of the marine protected area. This question was on a fourpoint answer scale of agree, disagree, neutral, or do not know. Neutral and do not know where grouped into one category. There was only one respondent that answered 'disagree' to this question which accounted for $0.3 \%$ and therefore the response was omitted from the regression analysis because of its little to no effect on the results. Approximately $50 \%$ of the sample responded with neutral or did not know compared to the $49.7 \%$ that responded with 'agree'.

The Chi-square test for the three variables was statistically significant at a level of significance 0.05 , with 10 degrees of freedom. The probability of obtaining the Chisquare values for the models given that there is no effect of the independent variables on the dependent variables is less than $0.1 \%$. All three models have a Cox \& Snell R Square 
value below .150 and Nagelkerke R Square values below .200, suggesting fairly weak models. Overall, the models correctly predicted the cases approximately $68 \%$ of the time. The prediction shows the percentage of cases for which the dependent variables were correctly predicted given the model. The logistic regression equation can be used to predict the dependent variables from the independent variables. From the independent variables being used, EDUCATION, RESIDENCY and LIVED were seen to be statistically significant and therefore the coefficients in the logistic regression equation are different from zero. All other variables being tested were not statistically significant in the regression equation. The test of Normality showed the residual values to be approximately normal (See figure 9-11). The Hosmer and Lemeshow Test describe whether the predicted probabilities for the dependent variables match the observed probabilities. For the dependent variables there is little evidence for lack of fit in the logistic regression models.

\section{THE RELATIONSHIP BETWEEN LOCAL SUPPORT AND ECONOMIC GROWTH}

A Spearman's Rho analysis concluded that there is a relationship between the perceived increase in job opportunities in the community attributed to the park and support for marine protection. An increase in opportunity for economic growth of the municipality will ultimately benefit the community and influence the community to support the source of growth for the town (Spearman's Rho, $\mathrm{p}=0.01$; Table 6). The results showed that all Spearman Rho values were close to 1, ranging from .732-.853 and showing a significant relationship between the variable JOBOPPORTUNITIES and the other four variables being assessed (SUPPORTESTABLISHMENT, INFAVOR, 
OVERALL, and CREATION). Table 6 depicts the Spearman Rho values for the variables, along with the sample sizes for each location, with a significance level of 0.01 .

\section{DISCUSSION}

The attitudes and perceptions towards marine protection of local communities in developing countries are important for the successful conservation of marine resources. One of the most crucial aspects for both the conservation of marine resources and promoting the local economy is understanding the principal variables that influence the attitudes of local community residents (Sesabo et al., 2006). In this study, support for marine protection depended on various demographic indicators and relationships between variables. The evidence in my study supports the idea that ethics and attitude are important factors influencing someone's intention or drive to help their local environment and can be used as a predictor of other environmental actions (Barr and Gilg, 2007). The environmental rights of the people of Puerto Morelos, Mx., influence the actions of the community through their belief that they have a right to use their marine resources sustainably for the local community as well as for future generations. Ultimately, protecting their rights leads to environmentally friendly behavior geared toward protecting their coastal resources, which is similarly seen in the results of Barr and Gilg's (2007) study.

The chi-square analyses conducted on categorical variables indicate the majority of the variables to be dependent on location of residence. 18 variables were significantly different and therefore demonstrating that locality plays a role in the individual's response. Whether the participant believes his or her livelihood depends on the protection 
of the reef was not statistically significant and is reliant on which side of the community the participant lives $\left(\chi^{2}=.739, \mathrm{p}=.390\right)$. The results verify the suggestion that residents living closer to the reef, or La Playa, would consider their employment dependent on the protection of their marine resources. Similarly, individuals living further inland in $\mathrm{La}$ Colonia would not consider their profession to be dependent on marine protection, which may be the result of a wider variety of occupations that do not relate directly to the marine environment. To some degree, most forms of livelihood in the population are directly related or dependent on the marine resources but their perception of dependency changes based on the location of residency. The variables focused on receiving citations (CITATION, $\left.\chi^{2}=3.372, p=.066\right)$ and agreeing with the creation of the MPA (CREATION, $\chi^{2}=6.103, \mathrm{p}=.107$ ) relate directly to where in the town the participants reside for similar reasons given above. Individuals interacting directly with the beach and MPA that reside in La Playa are more likely to be given a citation than individuals who live further from the coast and do not travel to the area. It is presumed that many individuals were afraid to admit they had received a citation for violation of a park rule or regulation. Individuals living closer to the coastline were more likely to agree to the creation of the MPA, which may be a result, in part, to their daily interaction with this side of the municipality. Gender of participants in the study was also dependent on location but the $p$-value obtained was very close to that of the significance value ( $\alpha=$ 0.05 ), therefore depicting the likely possibility that gender is independent of location. 


\section{PLACE OF RESIDENCY INFLUENCING KNOWLEDGE AND PERCEPTION}

The results of the Mann-Whitney test conclude that most of the categorical

variables tested showed a statistically significant difference in the level of knowledge and positive perception between locations of residency, therefore demonstrating that locality is an important influence on community perception. More than half of the variables showed La Playa to have higher mean rank scores, which indicate that these significant variables influence the knowledge level of residents in La Playa to an advanced stage of understanding for marine protection. More specifically, education played a role in the positive perception towards marine protection and the differences in perception for both groups. It is assumed that the more education an individual has experienced, the more understanding and well informed they are about marine resources and the importance of their protection. La Playa had a higher mean rank score suggesting that residents living closer to the park were positively influenced by education to favor marine protection. On average, awareness of the national park's existence between locations was statistically different but with La Colonia having a higher mean rank score. The disparity in score suggests that the recognition of residents in La Colonia of the park, influences their level of support. A similar result was seen with those who work for the park, knowledge of the park rules, agreeing with the regulations, knowing park employees, and agreeing with the creation of the park, which therefore influence their support for the MPA and are influenced by location of residency. There was a significant difference seen between levels of knowledge of each community in relation to being satisfied with the parks establishment as well as the increase in the amount of job opportunities for community members. In both these cases, La Playa had a higher mean rank score, signifying the level 
of satisfaction and the increase in job opportunities influencing their positive outlook more than those residing in La Colonia. The influence may be a result, in part, to residents living closer to the park benefiting more from jobs created by the park, than those that live further from the marine protected area. The same idea is seen for the courteousness of the park staff towards residents, effective management of the park, better protection overall and in relation to biodiversity, effective tourism management, and the overall creation of the marine park. Participants residing in La Playa are more readily influenced by these factors approving marine protection. For the variables that were not considered significant, there was no difference between knowledge base and attitudes in males and females for both subpopulations. The same is seen with the perceived dependency on the MPA, being given a citation, and the belief that the MPA is improving the number of fish in the area. For these variables, there was no major difference between the types of responses received and their location of residency did not affect their attitudes towards marine conservation. The lack in difference most likely relates to the type of question being asked to the participant. As seen in the chi-square analysis in table 3, gender was close to the significance level to be independent of location. Therefore, we would assume that gender would have no affect on a positive opinion towards marine conservation, because it was independent of location. The same can be said for the perceived level of dependency on the MPA and whether or not the individual received a citation for violating park regulations. These two variables do not depend on where the individuals live and we would therefore assume that it has no control over their views towards marine protected areas. The level of awareness of increasing fish stocks because of the protection of the area did not differ based on 
location. There was no real difference between increasing fish stock awareness in both communities. The similarity may be a result of the fishermen stakeholder group being more aware of the MPA's ability to increase fish numbers because of their direct interaction with the park and fish species. The remaining variables relating to sea grass protection, tourism management, efficient park rules, and the overall creation of the MPA, have an influence on the community's level of awareness of marine protection and their positive attitudes towards protecting their marine resources. For these variables, there was a difference between the communities' knowledge and understanding of the various subject matters with La Playa showing more support and understanding for protection. The differentiation may be because of the close connection and proximity residents in La Playa have with the MPA, the visitor center and educational campaigns. The direct exposure of inhabitants in La Playa to the MPA and its management can influence their opinions and attitudes overtime.

\section{THE IMPORTANCE OF DEMOGRAPHIC INDICATORS AND PUBLIC} PERCEPTION

Previous studies have shown that some of the most significant factors influencing a positive environmental action are demographic indicators. Environmentally friendly decisions are being influenced by moral and cultural beliefs (Barr and Gilg 2007). The results of the logistic regression analysis suggest that the level of education, nationality, and the total amount of time the individual has lived in Puerto Morelos, Mx., influenced the publics overall perception and conservation attitudes. It is important to note, as previously mentioned in the results, the strength of the models used are moderately weak which may signify the models not being sufficient as a result of correctly predicting the 
results $66-68 \%$ of the time. These demographic indicators significantly influence the perceived attitude of the household towards marine conservation. The dependent variables used focused on being in favor of the parks creation, being in favor of the rules and regulations, and being pleased overall with the MPA's creation. These variables were specifically chosen to determine which demographic indicators influence the public's perception.

In the first model, the idea of supporting the MPA was compared to the demographic indicators. The coefficient of the variable for educational level was statistically significant which means that those with higher levels of education support the creation of the marine protected area. The education system of Puerto Morelos may have contributed to the local communities understanding of their marine resources and the need for protection. The coefficient for place of birth of the residents was negative and was statistically significant suggesting that the nationality or country of origin of the participants influences their level of support for the creation of the marine protected area. Nationality influences support because of what country or part of Mexico the individual is originally from. Individuals born in countries further away from the town of Puerto Morelos were less likely to support marine protection. Individuals from parts of Mexico without coastal zones may not be as knowledgeable on marine protection and therefore less likely to support their creation. In relation to the amount of time one resides in Puerto Morelos, the coefficient was slightly positive and was also statistically significant. The result shows that the longer a resident lives in Puerto Morelos the more support they will have for the creation of the marine protected area. The longer someone resides in the 
town the more experience they have with the marine park and therefore are more likely to understand their dependency on the resources and the need for its protection.

In the second model, being in favor of the rules and regulations was compared to the demographic indicators. The educational level of the participants was statistically significant, verifying that those with higher levels of education are in favor of the rules and regulations set forth by the managers of the marine park. Educational level influences support because of the education system of Mexico. More exposure to marine and resource education will more often than not show individuals the importance of resource conservation. The birthplace of participants was statistically significant as well. These findings are similar to the first model where the nationality or country of origin of the participants influences their support for park regulations. Individuals born in countries further away from the town of Puerto Morelos, Mx., were less likely to support marine protected areas. Some countries of origin may not have the same laws and implementation for marine protection. Similarly, other states in Mexico may have different levels of marine and resource protection that do not match those of Puerto Morelos, Mx., therefore they may be less likely to support strict protection of a resource that would limit their use and would not otherwise be protected in their home town. The amount of time one has lived in Puerto Morelos was significant. The result shows that the longer a resident lives in Puerto Morelos, the more likely they are to support MPA regulations. The longer someone resides in the town the more experience they have with the marine park and therefore are more likely to understand the need for resource conservation and protection. 
In the last model, the overall satisfaction for the creation of the MPA was compared to the same demographic indicators. The educational level again played a significant role in the participants overall creation and management of the park demonstrating that those with higher levels of education were satisfied with the overall creation of the park. The influence of education can be attributed again to the education system of Mexico and the growing understanding of marine protection. Place of birth of participants was again statistically significant. These findings suggest again that the nationality or country of origin of the participants influences their level of support for the creation of the marine protected area. Individuals born in nations further away from the town of Puerto Morelos were less satisfied with the overall creation of the marine protected area. Some countries may not provide benefits, but rather increase the costs associated with living in close range to a marine reserve. Similarly, individuals from parts of Mexico without coastal zones may not be satisfied with its creation because there is no need for marine protection in their nation state and therefore are less likely to support its creation. The average time a participant resided in the town was also statistically significant. The result shows that the longer a resident lives in Puerto Morelos, Mx., the higher the level of satisfaction is for the creation of the marine reserve. The more time someone resides in the town the more likely they are to understand the need for coastal marine protection.

\section{LOCAL SUPPORT WITH INCREASED ECONOMIC GROWTH}

The results of the nonparametric correlation (Spearman's Rho; Table 6), suggest that residents are more likely to support marine protection and the establishment of MPA's when there is a perceived increase in job opportunities and economic growth of 
the community because of the marine park. Variables focusing on support for marine conservation were compared with the MPAs ability to increase job opportunities to demonstrate the relationship between marine support and community growth. Each of the variables was seen to have a significant relationship with increases in job opportunity. The Spearman's Rho values are highly positive, suggesting that support for marine protection on both sides of the municipality will increase as the economic well being of the community increases because of the protected area. The establishment of the park has improved the opportunity for employment in the tourism industry with increases in snorkeling, diving, and tourism operators, therefore increasing the number of jobs in the area and the influx of funds for the community. If the MPA continues to improve the financial system of the town, then residents will continue to support the establishment and management of the protected area.

\section{FUTURE SUGGESTIONS FOR MARINE CONSERVATION}

Marine protected areas are considered a good tool for protection against degradation and the collapse of marine resources, but small percentages of MPA's actually reach their objectives and are considered effective (Hind et al., 2010). Marine protected areas are designed, created and implemented through socio-economic factors as well as political processes, demonstrating the importance of social science studies. The differences seen between the two locations in Puerto Morelos, Mx., is an indication that more focus should be put on evenly providing information in regards to the park to both communities. High levels of dependency on marine resources usually lead to higher levels of support for protection because of the incentive to enforce and protect the natural resource, but this may not always be enough (Sale et al., 2005). According to Rodriquez- 
Martinez and Ortiz (1999), more than 50\% of the residents in Quintana Roo are immigrants from other Mexican states and $60 \%$ of the residents have resided in Quintana Roo for less than 10 years. Inland residents that move to coastal areas have no connection with the sea, which can be seen in Cancun, Mx., and Playa Del Carmen, Mx., where most individuals move for better job opportunities. When their studies were conducted in 1999, one year after the establishment of the Puerto Morelos National Marine Park, the majority of the residents were born and raised in Puerto Morelos and therefore had a strong connection with their marine resource. The present study, conducted over 10 years later, shows a shift in the demographics of Puerto Morelos to one similar to Cancun and Playa Del Carmen, which may be because of increases in population and prices in these cities, making Puerto Morelos an affordable alternative for immigrants looking for housing and work. Many residents in Puerto Morelos can be classified as "temporary residents" living in the area as a means to commute to other cities for work, including Cancun and Playa del Carmen, which causes a disconnect between locals and their perceived dependency on the nearby marine resources. Economic stability and support from protected areas can increase the quality of life of citizens and ultimately continue the support for conservation (Sale et al., 2005), which is verified by this study with increased MPA support from local residents of Puerto Morelos when economic growth is a product of marine protection. The success of any protected area can only be reached through continuous communication and support of science, the community and policy makers (Bellwood et al., 2004). Increasing the number of no take areas and the relative size of an MPA based on the use of the resource is important and conservation methods should be expanded to international areas. Therefore, protection should begin on a regional scale 
with a comprehensive, proactive approach to protection with both the local community and the government (Bellwood et al., 2004). Management strategies to protect marine resources should minimize the local impacts by having managers employ other tools that best fit a reserve. Realistic expectations need to be set for the reserves in order to be successful in conservation (Mumby and Steneck, 2008).

Similar protection methods used in terrestrial systems can be adapted for marine ecosystems. Schwartzman et al., (2000) discussed the importance of including indigenous and conservation interest into management practices. The authors noticed that the forest is a fragile system that can only be maintained when human interaction is low. Coral reels are considered the "rainforest" of the sea and should be viewed similarly as fragile systems that need protection. One controversial suggestion made by Knowlton and Jackson (2008), puts the pressure and responsibility of marine protection on developed countries that have the financial support and alternative food sources to help povertystricken areas struggling with protecting their marine resources. Economic incentives need to be included into management systems in order to prevent the overexploitation of resources and critical species. Education should also be a main focus as one of the best methods to improve support and reach conservation goals. Communities dependent on marine resources need to be educated and increase awareness of stakeholders (Bellwood et al., 2004; Schwartzman et al., 2000; Sale et al., 2005). For my study, the campaign for continuing marine protection must be expanded to areas further from the coastline and continued through extended vital educational programs to various groups, including elementary, secondary and high school students, current residents, and "temporary residents." The educational programs created must be able to improve teacher's 
knowledge about coral reefs, increase cooperation between the Department of Education and Environment, Non-Governmental Organizations and MPA managers, and enhance the role of scientist to develop public understanding of scientific research (RodriquezMartinez and Ortiz, 1999). One of the most important associations to study is the intention-behavior relationship, seen in the conceptual model of figure 2, which can help close the moral-environmental action gap. The relationship between intention and behavior needs to be looked at further rather than focusing only on the relationship between factors and problems. Analyzing this relationship can improve the understanding of why there is positive or negative environmental action and can further be supported by including psychological approaches into studies for implementation of marine regulation. This will demonstrate the importance of the relationship for policy makers to relate everyday practices and environmental action at the local level in order to promote positive behaviors (Barr and Gilg, 2007). Closing these knowledge gaps can improve the effectiveness of marine protection and help reach the goals set out by park managers (Schwartzman et al., 2000). Similarly, incorporating scientist into marine protection and management is essential to help promote basic scientific literacy and to communicate positive attitudes and values that improve the sensitivity towards reefs therefore beginning to close knowledge gaps (Rodriquez-Martinez and Ortiz, 1999). Improvements need to be made to the community and government's joint ability to enforce the regulations and instate monitoring programs to evaluate the effectiveness of the reserve. Enforcement is a key factor and should be continuous to keep the support of the people and prevent a loss of interest in conservation (Sale et al., 2005). 
People inhabit ecosystems regularly and these systems cannot be protected without the interaction of humans. Therefore communities should be included into management systems in order to achieve a better quality of life, prosperity and continue sustainable resource practices (Schwartzman et al., 2000). Promoting individuals to "think globally, act locally" is an important part of encouraging people to change their lifestyles for both local and global environmental issues. In order to solve an environmental concern we need to educate and make individuals aware of these issues and how they contribute to the problem, as well as provide them with information on how to solve them. Although, these behaviors must be corrected through a social psychological approach to studying environmental behaviors and decisions. Changing the behaviors will ultimately lead to positive decisions and actions that will change an overall behavior (Barr and Gilg, 2007). The overall relationship between a behavior and an action is complex, but we need a better understanding of what drives human behavior and behavioral change. Increasing public awareness and understanding through positive educational experiences can aide in the understanding of this relationship between behavior and change to reach a long-term preservation of resources (Rodriquez-Martinez and Ortiz, 1999). Blame should not be placed on who is responsible for protecting their marine resources. More focus should be placed on how to shape the way people think and feel about an issue and therefore influence their behavior to act in a manner that is positive (Halpern et al., 2004) towards these important marine ecosystems. 


\section{REFERENCES}

Agardy, T., Bridgewater, P., Crosby, P. M., Day, J., Dayton, P., Kenchington, R., Laffoley, D., McConney, P., Murray, P., Parks, J., and Peau, L. (2002). Dangerous targets? Unresolved issues and ideological clashes around marine protected areas. Aquatic Conserv: Mar. Freshw. Ecosyst. 13: 353-367.

Baldassare, M. And Katz, C. (1992): The personal threat of environmental problems as predictor of environmental practices. Environment and Behavior. 24(5): 602-616.

Ban, N. C., Picard C., Vincent, A. C. J. (2008). Moving towards spatial solutions in marine conservation with indigenous communities. Ecology and Society. 13(1): 32 1-20.

Beger, M., Harborne, A. R., Dacles, T. P., Solandt, J., and Ledesma, G. L. (2005). A framework of lessons learned from community-based marine reserves and its effectiveness in guiding a new coastal management initiative in the Philippines. Environmental Management. 34(6): 786-801.

Bellwood, R. D., Hughes, P.T., Folke, C., and Nystrom, M. (2004). Confronting the coral reef crisis. Nature. 429: 827-833.

Broad, K. and Sanchirico, J. N. (2008). Local perspectives on marine reserve creation in the Bahamas. Ocean \& Coastal Management. 51(11): 763-771.

Camargo, C., Maldonado, J. H., Alvarado, E., Moreno-Sánchez, R., Mendoza, S., Manrique, N., Mogollón, A., Osorio, J. D., Grajales, A., and Sanchez, J. A. (2009). Community involvement in management for maintaining coral reef resilience and biodiversity in southern Caribbean marine protected areas. Biodivers Conserv. 18: 935956.

Cameron, L.D., Brown, P.M. and Chapman, J.G. (1998): Social value orientations and decisions to take pro-environmental action. Journal of Applied Social Psychology. 28(8): 675-697.

Christie, P., Pollnac, R. B., Oracion, E. G., Sabonsolin, A., Diaz, R., and Pietri, D. (2009). Back to basics: An empirical study demonstrating the importance of local-level dynamics for the success of tropical marine ecosystem-based management. Coastal Management. 37(3): 349 -373.

Christie, P., White, A. and Deguit, E. (2002). Starting point or solution? Community based marine protected areas in the Philippines. Journal of Environmental Management. 66: $441-454$. 
Cinner, J. E., Marnane, M. J., and McClanahan, T.R. (2005). Conservation and community benefits from traditional coral reef management at Ahus Island, Papua New Guinea. Conservation Biology. 19(6): 1714 - 1723.

Cocklin, C., Craw, M., and Mcauley, I. (1998). Marine reserves in New Zealand: use rights, public attitudes, and social impacts. Coastal Management. 26(3): 213-231.

Corraliza, J.A. and Berrenguer, J. (2000): Environmental values, beliefs, and actions: a situational approach. Environment and Behavior. 32 (6): 832-848.

De Young, R. (1986). Some psychological aspects of recycling. Environment and behavior. 18 (4): 435-449.

De Young, R. (1996). Some psychological aspects of reduced consumption behavior: the role of intrinsic satisfaction and competence motivation. Environmental and Behavior. 28 (3): 358-409.

Doren, R. F., Trexler, J. C., Gottlieb, A. D., and Harwell, M. C. (2009). Ecological indicators for system-wide assessment of the greater everglades ecosystem restoration program. Ecological Indicators 9S: 2-16.

Florida Department of Environmental Protection. (2011). Biscayne Bay Aquatic Preserves Management Plan (Draft). Coastal and Aquatic Managed Areas. 168 pp.

Granek, F. E., and Brown, A. M. (2005). Co-management approach to marine conservation in Moheli Comoros Islands. Conservation Biology. 19(6): 1724-1732.

Halpern, D., Bates, C., Beales, G. And Heathfield, M. A. (2004). Personal responsibility and changing behaviour: The state of knowledge and its implications for public policy. Cabinet Office, London.

Heinen, J. T. and Shrivastava R. J. (2009). An analysis of conservation attitudes and awareness around Kaziranga National Park, Assam, India: Implications for conservation and development. Population and Environment. 30(6): 261-274.

Hind, E. J., Hiponia, M. C., and Gray, T.S. (2010). From community-based to centralized national management - A wrong turn for the governance of the marine protected area in Apo Island, Philippines? Marine Policy. 34: 54-62.

Infield, M. (2001). Cultural values: a forgotten strategy for building community support for protected areas in Africa. Conservation Biology. 15(3): 800-802.

Johannes, R. E. (2002). The renaissance of community-based marine resource management in oceania. Annu. Rev. Ecol. Syst. 33: 317-340. 
Jones, P. J. S. (2002). Marine protected area strategies: issues, divergences, and the search for middle ground. Reviews in Fish Biology and Fisheries. 11: 197-216.

Knowlton, N. and Jackson, J. B. C. (2008). Shifting baselines, local impacts, and global change on coral reefs. PLoS Biology. 6(2): 215-220.

Kritzer, J. P. (2004). Effects of noncompliance on the success of alternative designs of marine protected-area networks for conservation and fisheries management. Conservation Biology. 18(4): 1021-1031.

Lam, S-P. (1999). predicting intentions to conserve water from the theory of planned behavior, perceived moral obligation, and perceived water right. Journal of Applied Social Psychology. 29(5): 1058-1071.

Lundquist, C. J., and Granek, E. F. (2005). Strategies for successful marine conservation: integrating socioeconomic, political, and scientific factors. Conservation Biology. 19(6):6 1771-1778.

Mainieri, T., Barnett, E.G., Valdero, T.R., Unipan, J.B. And Oskamp, S. (1997). Green buying: the influence of environmental concern on consumer behavior. Journal of Social Psychology. 137 (2): 189-204.

Mumby, P. J. and Steneck, R. S. (2008). Coral reef management and conservation in light of rapidly evolving ecological paradigms. Trends in Ecology and Evolution. 23:10 555674.

Murray, G. D. (2005) Multifaceted measures of success in two Mexican marine protected areas. Society \& natural resources. 18(10): $889-905$.

Nancarrow, B.E., Smith, L.M. And Syme, G.J. (1996-1997). The ways people think about water. Journal of Environmental Systems. 25(1): 15-27.

Roberts, J.A. (1996). Green consumers in the 1990's: profile and implications for advertising. Journal of Business Research. 36 (3): 217-231.

Rodriquez-Martinez R. E. (2006). Community involvement in marine protected areas: case of Puerto Morelos reef, Mexico. Environmental Management. 88:1151-1160.

Rodriguez-Martinez, R., and Ortiz, L. M. (1999). Coral reef education in schools of Quintana roo, Mexico. Ocean \& Coastal Management. 42: 1061-1068.

Sadalla, E.K. And Krull, J.L. (1995). Self-presentational barriers to resource conservation. Environment and Behavior. 27(3): 328-353.

Sale, F. P., Cowen, K. R., Danilowicz, S. B., Jones, P. G., Kritzer, P. J., Lindeman, C. K., 
Planes, S., Polunin, V.C. N., Russ, R. G., Sadovy, J. Y., and Steneck, S. R. (2005). Critical science gaps impede use of no-take fishery reserves. TRENDS in Ecology and Evolution. 20:74- 80.

Samuelson, C.D. and Biek, M. (1991). Attitudes toward energy conservation: a confirmatory factor analysis. Journal of Applied Social Psychology. 21(7): 549-568.

Schwartzman, S., Nepstad, D., and Moreira, A. (2000). Arguing tropical forest conservation: people versus parks. Conservation Biology. 14(5): 1370-1374.

Sesabo, J. K., Lang, H., Tol, R. S. J. (2006). Perceived attitude and marine protected areas (mpas) establishment: why household's characteristics matter in coastal resources conservation initiatives in Tanzania. Working Papers. FNU-99 1-39.

Sguin, C., Pelletier, L.G. And Hunsley, J. (1998). Toward a model of environmental activism. Environment and Behavior. 30(5): 628-652.

Stamieszkin, K., Wielgus, J. and Gerber, L. R. (2009). Management of a marine protected area for sustainability and conflict resolution: Lessons from Loreto Bay National Park (Baja California Sur, Mexico). Ocean \& Coastal Management. 52: 449-458.

Stern, P.C., Dietz, T. and Guagnano, G.A. (1995). The new ecological paradigm in social-psychological context. Environment and Behavior. 27(6): 723-743.

Suman, D. Shivlani, M. and Milon J. W. (1999) Perceptions and attitudes regarding marine reserves: A comparison of stakeholder groups in the Florida Keys National Marine Sanctuary. Ocean and Coastal Management. 42(12): 1019-1040.

Thur, S. M. (2010). User fees as sustainable financing mechanisms for marine protected areas: an application to the bonaire national marine park. Marine Policy. 34: 63-69.

Tissot, B. N., Walsh, W. J. and Hixon, M. A. (2009). Hawaiian islands marine ecosystem case study: ecosystem and community-based management in Hawaii. Coastal Management. 37(3): 255 - 273.

Tonioli C. F., and Agar, J. J. (2009). Extending the Bajo de Sico, Puerto Rico, seasonal closure: an examination of small-scale fishermen's perception of possible socioeconomic impacts on fishing practices, families, and community. Marine Fisheries Review. 71(2): 15-23.

Tongson, E. and Cola, R. (2007). Negotiating stakeholder agreements for conservation: the case of Tubbataha reefs, Philippines. Science Diliman. 19(1): 47-63. 
White, A. T., Courtney, C.A. and Salamanca, A. (2002). Experience with marine protected area planning and management in the Philippines. Coastal Management. 30: 126. 
APPENDICES 
Appendix 1 - Semi-structured Formal Survey for Residents of Puerto Morelos, Mexico 


\section{Interview for residents of Puerto Morelos, Mexico}

Age

Gender M F Education Level

Number of adults in the household children (under 18)

Total:

Occupation of adult (s):

How long have you lived in Puerto Morelos (years)

Hometown / state / country

1. Did you know that there is a national park (protected area) in Puerto Morelos? Y N

2. Do you work within the national park? Y N

3. Does your work depend on the national park? Y N

4. Are you aware of the rules the marine protected area management plan has in place?: $\mathrm{YN}$

5. If so, how did you become familiar with them?

6. Are you in favor of the rules? Yes - all of them; Yes - some of them; No - do not

7. Please explain your answers: (open answer)

8. Do you know any employees currently working in the protected area? Y N

9. Have you or a family member ever been fined, punished or warned for violating the rules established by the marine protected area? Y N 
10. If yes, please explain (open answer)

11. Do you agree with the creation of the marine protected area? Y N

12. Why or why not (open answer).

13. Please circle the answer that best fits your opinion about each statement:

a. I like the fact that the protected area was created: Agree; Neutral; Disagree; Don't Know Why (open answer)

b. The protected area has increased job opportunities: Agree; Neutral; Disagree; Don't Know Why (open answer)

c. The staff is professional and courteous: Agree; Neutral; Disagree; Don't Know Why (open answer)

d. In general, the park is managed well: Agree; Neutral; Disagree; Don't Know Why (open answer)

14. What are the major disadvantages of living near the protected area? (List all)

15. What are the main advantages of living near the protected area? (List all) 
16. Have you ever attended a public meeting concerning the marine protected area? Y N

17. If so, the experience was: positive neutral negative

18. Please explain your answer (open answer)

19. If not, why not?

20. Please circle the answer that best fits your opinion about each statement:

a. The corals are better protected now than before: Agree; Neutral; Disagree; Don't Know Why?

b. The protection is increasing the number of fish in the area: Agree; Neutral; Disagree; Don't Know Why?

c. The sea grasses are better protected now than before: Agree; Neutral; Disagree; Don't Know Why?

d. The current rules are adequate: Agree; Neutral; Disagree; Don't Know Why?

e. Tourism is managed better now than before: Agree; Neutral; Disagree; Don't Know Why?

f. Overall, I am pleased that the protected area was created: Agree; Neutral;

Disagree; Don't Know Why? 
Table 1. Descriptive Statistics for Demographic Variables

\begin{tabular}{|c|c|c|c|c|}
\hline Variable Description & Variable Name & Mean or Percent & $\begin{array}{l}\text { Minimum and } \\
\text { Maximum Values }\end{array}$ & $\begin{array}{l}\text { Standard } \\
\text { deviation }\end{array}$ \\
\hline $\begin{array}{l}\text { Household Location (1 if } \\
\text { 'La Playa', } 2 \text { if 'La } \\
\text { Colonia') }\end{array}$ & LOCATION & $\begin{array}{l}30.3 \% \text { La Playa } \\
69.7 \% \text { La } \\
\text { Colonia }\end{array}$ & & $\mathrm{N} / \mathrm{A}$ \\
\hline $\begin{array}{l}\text { Gender of Household } \\
\text { Head ( } 1 \text { if male, } 2 \text { if } \\
\text { female) }\end{array}$ & GENDER & $\begin{array}{l}65 \% \text { Male } \\
35 \% \text { Female }\end{array}$ & & $\mathrm{N} / \mathrm{A}$ \\
\hline $\begin{array}{l}\text { Age of Household Head } \\
\text { (Years) }\end{array}$ & AGE & 33.58 & $\begin{array}{l}\operatorname{Min}=15 \\
\operatorname{Max}=68\end{array}$ & 12.15 \\
\hline $\begin{array}{l}\text { Number of Adults in } \\
\text { household }\end{array}$ & ADULTS & 2.82 & $\begin{array}{l}\operatorname{Min}=1 \\
\operatorname{Max}=10\end{array}$ & 1.63 \\
\hline $\begin{array}{l}\text { Number of children under } \\
\text { age of } 18 \text { in household }\end{array}$ & CHILDREN & 1.33 & $\begin{array}{l}\operatorname{Min}=0 \\
\operatorname{Max}=8\end{array}$ & 1.44 \\
\hline $\begin{array}{l}\text { Educational level of } \\
\text { Household Head (1- } \\
\text { Elemenary, 2-Middle } \\
\text { School, 3- High School, } \\
\text { 4-College, 5-University) }\end{array}$ & EDUCATION & $\begin{array}{l}1-27.9 \% \\
2-26.6 \% \\
3-24.6 \% \\
4-12.1 \% \\
5-8.8 \%\end{array}$ & & $\mathrm{~N} / \mathrm{A}$ \\
\hline Size of Household & TOTAL & 4.15 & $\begin{array}{l}\operatorname{Min}=1 \\
\operatorname{Max}=14\end{array}$ & 2.62 \\
\hline $\begin{array}{l}\text { Average time living in } \\
\text { Puerto Morelos, MX. } \\
\text { (Years) }\end{array}$ & LIVED & 14.46 & $\begin{array}{l}\operatorname{Min}=1 \\
\operatorname{Max}=68\end{array}$ & 12.08 \\
\hline $\begin{array}{l}\text { Nationality/Place of Birth } \\
\text { of Household Head (1- } \\
\text { Mx., 2-Yucatan } \\
\text { Peninsula, 3-Outside of } \\
\text { Mx.) }\end{array}$ & RESIDENCY & $\begin{array}{l}1-32.3 \% \\
2-58.0 \% \\
3-9.7 \%\end{array}$ & & N/A \\
\hline
\end{tabular}




\begin{tabular}{llll}
\hline Occupation of Household & OCCUPATION & $18.3 \%$ & N/A \\
Head (highest $\%$ was & & & \\
Restaurant and food & & & \\
svc/skilled labor) & & & \\
\hline
\end{tabular}




\section{Table 2. Descriptive Statistics for Survey Questions}

\begin{tabular}{|c|c|c|c|}
\hline Variable Description & Variable Name & Mean or Percent & $\begin{array}{l}\text { Standard } \\
\text { Deviation }\end{array}$ \\
\hline Aware of MPA & AWARENESS & $\begin{array}{l}\text { Yes } 54.7 \% \\
\text { No } 45.3 \%\end{array}$ & N/A \\
\hline Employed by MPA & EMPLOYMENT & $\begin{array}{l}\text { Yes } 12.7 \% \\
\text { No } 87.3 \%\end{array}$ & N/A \\
\hline Dependent Employment & DEPENDENT & $\begin{array}{l}\text { Yes } 31.7 \% \\
\text { No } 68.3 \%\end{array}$ & $\mathrm{~N} / \mathrm{A}$ \\
\hline $\begin{array}{l}\text { Rules and Objectives of MPA } \\
\text { (aware of rules/objectives) }\end{array}$ & FAMILIARRULES & $\begin{array}{l}\text { Yes } 40 \% \\
\text { No } 60 \%\end{array}$ & N/A \\
\hline Media (If yes to CORRIENTE) & MEDIA & $\begin{array}{l}\text { Experience } 16 \% \\
\text { Unknown } 61.7 \%\end{array}$ & $\mathrm{~N} / \mathrm{A}$ \\
\hline Assent Regulations & INFAVOR & $\begin{array}{r}\text { Yes } 32.2 \% \\
\text { Some } 9.7 \% \\
\text { No } 58 \%\end{array}$ & N/A \\
\hline Park Personnel & PARKPERSONNEL & $\begin{array}{l}\text { Yes } 36.3 \% \\
\text { No } 63.7 \%\end{array}$ & N/A \\
\hline Citation & CITATION & $\begin{array}{r}\text { Yes } 8.7 \% \\
\text { No } 91.3 \%\end{array}$ & N/A \\
\hline Support MPA Establishment & SUPPORTESTABLISHMENT & $\begin{array}{l}\text { Yes } 55 \% \\
\text { No } 45 \%\end{array}$ & N/A \\
\hline MPA Creation (4 pt. scale) & CREATION & $\begin{array}{r}\text { Do Not Know - } \\
45.3 \% \\
\text { Disagree }-0.7 \% \\
\text { Neutral }-2.7 \% \\
\text { Agree }-51.3 \%\end{array}$ & N/A \\
\hline MPA \& Job Opportunities & JOBOPPORTUNITIES & $\begin{array}{r}\text { Do Not Know- } \\
51.3 \% \\
\text { Disagree }-1.3 \% \\
\text { Neutral }-8.7 \% \\
\text { Agree }-38.7 \%\end{array}$ & $\mathrm{~N} / \mathrm{A}$ \\
\hline Park Management Personnel & PROFESSIONAL & $\begin{array}{r}\text { Do Not Know - } \\
56.3 \% \\
\text { Disagree }-1.3 \% \\
\text { Neutral }-8.7 \% \\
\text { Agree }-33.7 \%\end{array}$ & N/A \\
\hline MPA Management Plan & MPAMANAGEMENT & $\begin{array}{r}\text { Do Not Know - } \\
56.3 \% \\
\text { Disagree }-1.3 \% \\
\text { Neutral }-7.3 \% \\
\text { Agree }-35.0 \%\end{array}$ & N/A \\
\hline MPA Public Event & PUBLICEVENT & $\begin{array}{r}\text { Yes } 27.7 \% \\
\text { No } 72.3 \%\end{array}$ & N/A \\
\hline $\begin{array}{l}\text { Public Event Experience (If yes } \\
\text { to REUNIONPUBLICA) }\end{array}$ & EXPERIENCE & $\begin{array}{r}\text { Positive } 24.7 \% \\
\text { Neutral } 2.7 \%\end{array}$ & N/A \\
\hline
\end{tabular}




\begin{tabular}{|c|c|c|c|}
\hline & & Negative $0.3 \%$ & \\
\hline MPA \& Coral Protection & CORAL & $\begin{array}{r}\text { Do Not Know - } \\
53.0 \% \\
\text { Disagree }-2.0 \% \\
\text { Neutral }-7.3 \% \\
\text { Agree }-37.7 \%\end{array}$ & N/A \\
\hline MPA \& Increased Fishstock & FISH & $\begin{array}{r}\text { Do Not Know - } \\
59.3 \% \\
\text { Disagree }-5.3 \% \\
\text { Neutral }-8.7 \% \\
\text { Agree }-26.7 \%\end{array}$ & N/A \\
\hline $\begin{array}{l}\text { MPA \& Seagrass Bed } \\
\text { Protection }\end{array}$ & SEAGRASS & $\begin{array}{r}\text { Do Not Know- } \\
57.7 \% \\
\text { Disagree }-3.3 \% \\
\text { Neutral }-5.7 \% \\
\text { Agree }-33.3 \%\end{array}$ & N/A \\
\hline Adequate Regulations & ADEQUATERULES & $\begin{array}{r}\text { Do Not Know - } \\
54.7 \% \\
\text { Disagree }-3.0 \% \\
\text { Neutral }-10.7 \% \\
\text { Agree }-31.7 \%\end{array}$ & N/A \\
\hline Tourism Management & TOURISM & $\begin{array}{r}\text { Do Not Know - } \\
49.3 \% \\
\text { Disagree }-3.0 \% \\
\text { Neutral }-8.0 \% \\
\text { Agree }-39.7 \%\end{array}$ & N/A \\
\hline Overall Creation of MPA & OVERALL & $\begin{array}{r}\text { Do Not Know - } \\
45.0 \% \\
\text { Disagree }-0.3 \% \\
\text { Neutral }-5.0 \% \\
\text { Agree }-49.7 \%\end{array}$ & N/A \\
\hline
\end{tabular}


Table 3. Chi-Square Analysis of Categorical Variables based on Location

\begin{tabular}{llcr}
\hline Variable Name & $\begin{array}{l}\text { Chi-Square } \\
\text { Value }\end{array}$ & df & $\begin{array}{r}\mathrm{p} \text {-value } \\
(\alpha=0.05)\end{array}$ \\
\hline GENDER & 3.545 & 1 & .060 \\
EDUCATION & 23.672 & 4 & .000 \\
AWARENESS & 8.060 & 1 & .005 \\
EMPLOYMENT & 7.964 & 1 & .005 \\
DEPENDENT & .739 & 1 & .390 \\
FAMILIARRULES & 6.057 & 1 & .014 \\
INFAVOR & 7.635 & 2 & .022 \\
PARKPERSONNEL & 9.716 & 1 & .002 \\
CITATION & 3.372 & 1 & .066 \\
SUPPORTESTABLISH & 5.105 & 1 & .024 \\
MENT & 12.103 & 3 & .107 \\
CREATION & 10.631 & 3 & .014 \\
JOBOPPORTUNITIES & 10.018 \\
PROFESSIONAL & 14.754 & 3 & .002 \\
MPAMANAGEMENT & 17.172 & 3 & .001 \\
PUBLICEVENT & 11.018 & 1 & .001 \\
EXPERIENCE & 12.662 & 3 & .005 \\
CORAL & 9.977 & 3 & .001 \\
\hline & & 3 & .019 \\
\hline
\end{tabular}




\begin{tabular}{lccc}
\hline SEAGRASS & 12.175 & 3 & .007 \\
ADEQUATERULES & 12.244 & 3 & .007 \\
TOURISM & 11.439 & 3 & .010 \\
OVERALL & 10.302 & 3 & .016 \\
\hline
\end{tabular}


Table 4. Hypothesis 1: Level of Knowledge and Perception Based on Location of Residence - Mann-Whitney Test

\begin{tabular}{|c|c|c|c|}
\hline Variable Name & Mean Rank & $\begin{array}{l}\text { Mann- } \\
\text { Whitney } U\end{array}$ & $\begin{array}{l}\mathrm{p} \text {-value }(\alpha= \\
0.05)\end{array}$ \\
\hline GENDER & $\begin{array}{l}\text { 162.29 La Playa } \\
\text { 145.37 La Colonia }\end{array}$ & 8437.0 & .060 \\
\hline EDUCATION & $\begin{array}{l}\text { 179.22 La Playa } \\
\text { 135.86 La Colonia }\end{array}$ & 6595.0 & .000 \\
\hline AWARENESS & $\begin{array}{l}\text { 131.95 La Playa } \\
\text { 158.58 La Colonia }\end{array}$ & 7821.5 & .005 \\
\hline EMPLOYMENT & $\begin{array}{l}\text { 138.18 La Playa } \\
\text { 155.86 La Colonia }\end{array}$ & 8388.5 & .005 \\
\hline DEPENDENT & $\begin{array}{l}\text { 145.25 La Playa } \\
\text { 152.78 La Colonia }\end{array}$ & 9032.0 & .391 \\
\hline FAMILIARRULES & $\begin{array}{l}\text { 134.68 La Playa } \\
\text { 157.39 La Colonia }\end{array}$ & 8069.5 & .041 \\
\hline INFAVOR & $\begin{array}{l}\text { 133.23 La Playa } \\
\text { 158.02 La Colonia }\end{array}$ & 7938.0 & .010 \\
\hline PARKPERSONNEL & $\begin{array}{l}\text { 130.82 La Playa } \\
\text { 159.07 La Colonia }\end{array}$ & 7719.0 & .002 \\
\hline CITATION & $\begin{array}{l}\text { 143.72 La Playa } \\
153.45 \text { La Colonia }\end{array}$ & 8892.5 & .067 \\
\hline
\end{tabular}




\begin{tabular}{|c|c|c|c|}
\hline SUPPORTESTABLISHMENT & $\begin{array}{l}\text { 135.75 La Playa } \\
\text { 156.92 La Colonia }\end{array}$ & 8167.0 & .024 \\
\hline CREATION & $\begin{array}{l}\text { 166.27 La Playa } \\
\text { 143.63 La Colonia }\end{array}$ & 8074.5 & .018 \\
\hline JOBOPPORTUNITIES & $\begin{array}{l}\text { 170.38 La Playa } \\
\text { 141.84 La Colonia }\end{array}$ & 7700.5 & .004 \\
\hline PROFESSIONAL & $\begin{array}{l}\text { 172.93 La Playa } \\
\text { 140.73 La Colonia }\end{array}$ & 7468.5 & .001 \\
\hline MPAMANAGEMENT & $\begin{array}{l}\text { 176.65 La Playa } \\
\text { 139.11 La Colonia }\end{array}$ & 7130.0 & .000 \\
\hline PUBLICEVENT & $\begin{array}{l}\text { 131.01 La Playa } \\
\text { 158.99 La Colonia }\end{array}$ & 7736.0 & .001 \\
\hline EXPERIENCE & $\begin{array}{l}\text { 169.97 La Playa } \\
\text { 142.02 La Colonia }\end{array}$ & 7738.0 & .001 \\
\hline CORAL & $\begin{array}{l}\text { 169.45 La Playa } \\
\text { 142.25 La Colonia }\end{array}$ & 7785.0 & .005 \\
\hline FISH & $\begin{array}{l}\text { 161.27 La Playa } \\
\text { 145.81 La Colonia }\end{array}$ & 8529.5 & .106 \\
\hline SEAGRASS & $\begin{array}{l}\text { 170.03 La Playa } \\
\text { 142.00 La Colonia }\end{array}$ & 7732.5 & .003 \\
\hline ADEQUATERULES & $\begin{array}{l}\text { 173.48 La Playa } \\
\text { 140.49 La Colonia }\end{array}$ & 7418.0 & .001 \\
\hline
\end{tabular}


TOURISM

OVERALL
173.19 La Playa

140.62 La Colonia

169.32 La Playa

142.21 La Colonia
7445.0

.001

7797.0

.005 
Table 5. Hypothesis 2 - Demographic Indicators affecting Public Perception \& Attitudes Towards Marine Conservation - Logistic Regression Analysis Summary

\begin{tabular}{llll} 
Model 1: Dependent & \multicolumn{3}{l}{ Variable $=$ SUPPORTESTABLISHMENT } \\
\hline $\begin{array}{l}\text { Demographic } \\
\text { Indicator }\end{array}$ & $\begin{array}{l}\text { Estimated } \\
\text { Coefficients }\end{array}$ & Standard Error & P-value \\
\hline AGE & .011 & .012 & .352 \\
GENDER & .007 & .276 & .979 \\
EDUCATION & 1.379 & .365 & .003 \\
LOCATION & -.267 & .301 & .375 \\
RESIDENCY & -.943 & .299 & .000 \\
LIVED & .042 & .013 & .001 \\
\hline
\end{tabular}

Likelihood Ratio (model chi-square): 49.636 (d.f. =10, $P=.000) ;$ percent of right prediction: 68.7

Model 2: Dependent Variable $=$ INFAVOR

\begin{tabular}{llll}
\hline $\begin{array}{l}\text { Demographic } \\
\text { Indicator }\end{array}$ & $\begin{array}{l}\text { Estimated } \\
\text { Coefficients }\end{array}$ & Standard Error & P-value \\
\hline AGE & .002 & .012 & .859 \\
GENDER & -.201 & .276 & .466 \\
EDUCATION & 1.059 & .372 & .030 \\
LOCATION & -.479 & .293 & .102 \\
RESIDENCY & -.685 & .298 & .021 \\
LIVED & .045 & .013 & .000 \\
\hline
\end{tabular}

Likelihood Ratio (model chi-square): 46.548 (d.f. =10, $P=.000)$; percent of right prediction: 68.4

Model 3: Dependent Variable $=$ OVERALL

\begin{tabular}{llll}
\hline $\begin{array}{l}\text { Demographic } \\
\text { Indicator }\end{array}$ & $\begin{array}{l}\text { Estimated } \\
\text { Coefficients }\end{array}$ & Standard Error & P-value \\
\hline AGE & .003 & .012 & .829 \\
GENDER & .111 & .275 & .686 \\
EDUCATION & 1.266 & .365 & .005 \\
LOCATION & -.490 & .297 & .098 \\
RESIDENCY & -.869 & .299 & .004 \\
LIVED & .046 & .013 & .000 \\
\hline
\end{tabular}

Likelihood Ratio (model chi-square): 48.322 (d.f. $=10, P=.000)$; percent of right prediction: 66.6 
Table 6. Hypothesis 3: Local Support and Economic Growth - Spearman's Rho

\begin{tabular}{|c|c|c|c|}
\hline Variable Name & $\mathrm{N}$ & $\begin{array}{l}\text { Spearman's } \\
\text { Rho }\end{array}$ & $\begin{array}{l}\text { Sig. (2-tailed) }(\alpha \\
=0.01)\end{array}$ \\
\hline SUPPORTESTABLISHMENT & $\begin{array}{l}\text { 91 La Playa } \\
209 \text { La Colonia }\end{array}$ & $\begin{array}{l}.802 \text { La Playa } \\
.829 \text { La Colonia }\end{array}$ & .000 \\
\hline INFAVOR & $\begin{array}{l}91 \text { La Playa } \\
209 \text { La Colonia }\end{array}$ & $\begin{array}{l}.732 \text { La Playa } \\
.804 \text { La Colonia }\end{array}$ & .000 \\
\hline OVERALL & $\begin{array}{l}90 \text { La Playa } \\
209 \text { La Colonia }\end{array}$ & $\begin{array}{l}.850 \text { La Playa } \\
.820 \text { La Colonia }\end{array}$ & .000 \\
\hline CREATION & $\begin{array}{l}\text { 91 La Playa } \\
209 \text { La Colonia }\end{array}$ & $\begin{array}{l}.853 \text { La Playa } \\
.822 \text { La Colonia }\end{array}$ & .000 \\
\hline
\end{tabular}




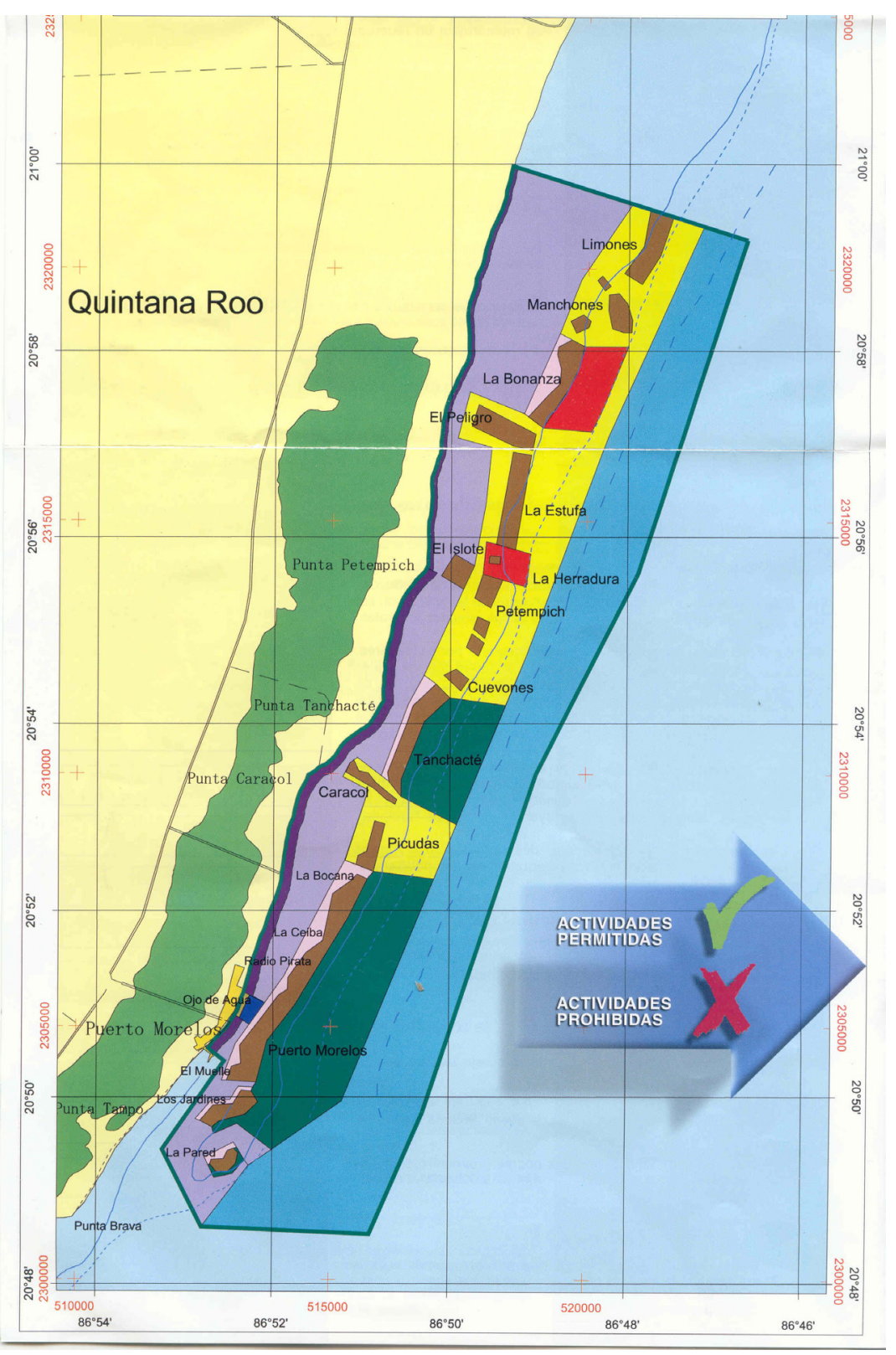

Figure 1. Puerto Morelos National Marine Park Multiple use zonation map 


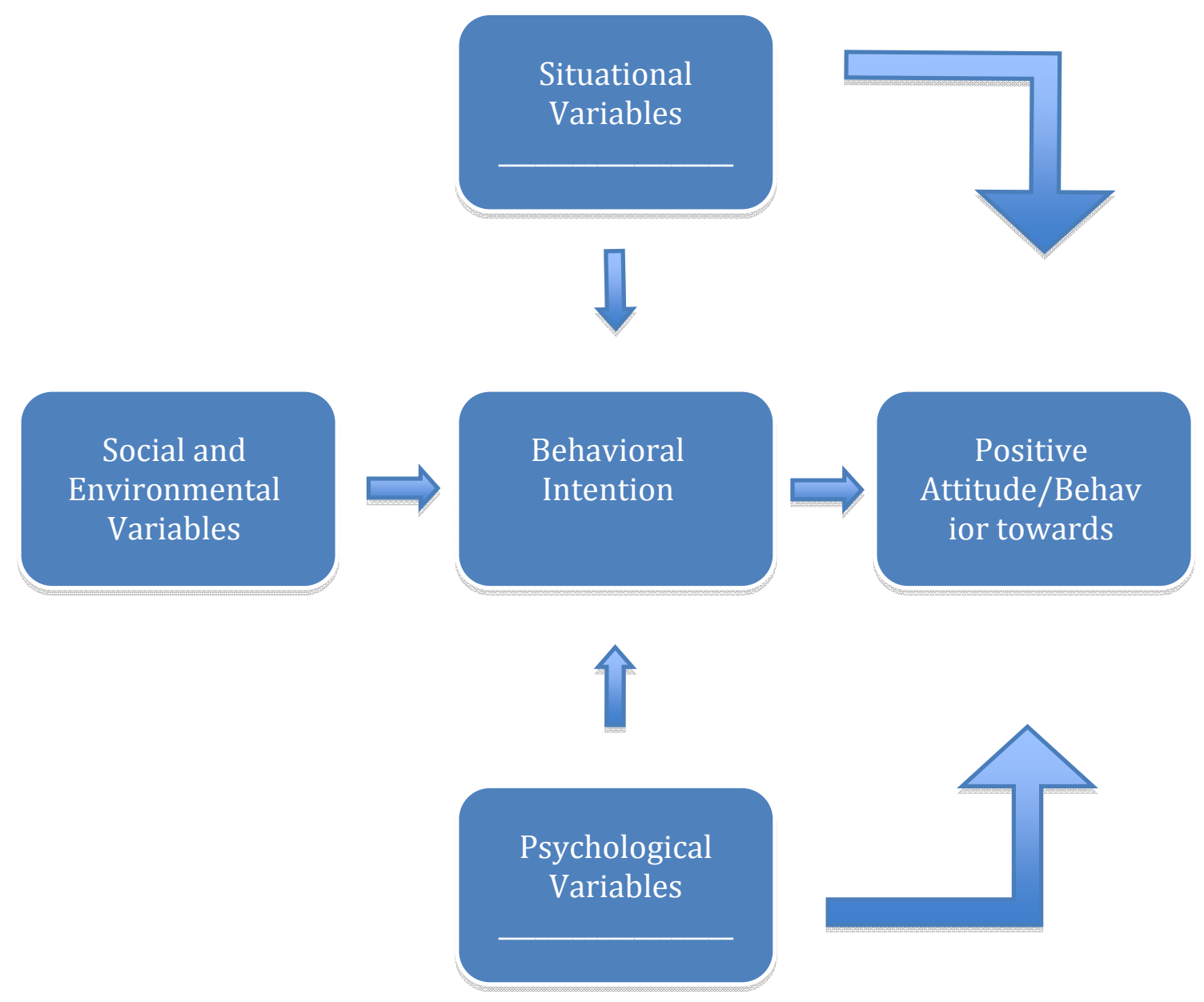

Figure 2. Information Deficit Linear Model Showing the Relationship between Social Factors and Variables with Environmental Behavior (Barr and Gilg, 2007). 


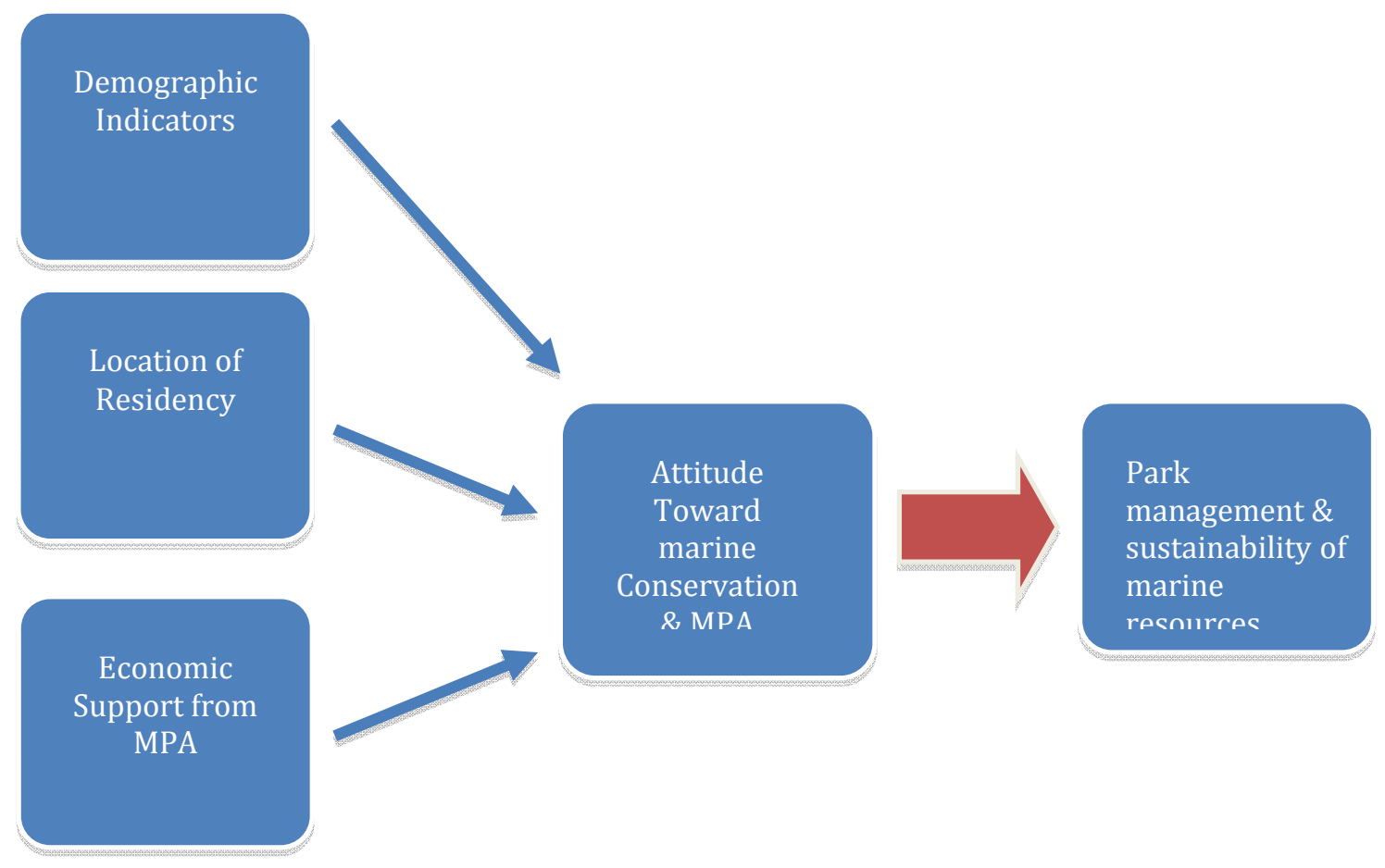

Figure 3. The relationship between variables that structure the attitudes of households towards marine conservation in Puerto Morelos, Mexico (Sesabo et al., 2006) 


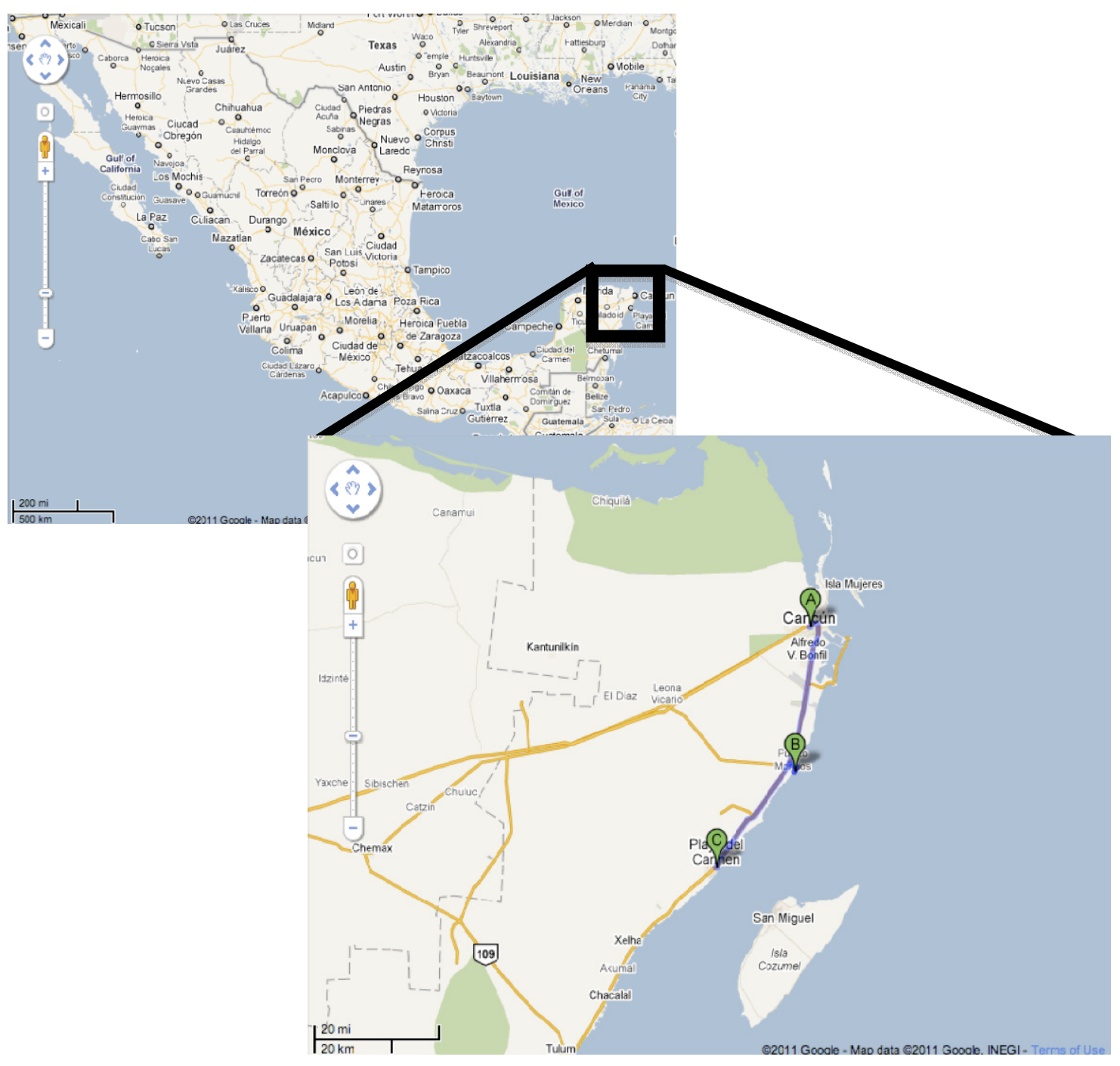

Figure 4. Puerto Morelos, Quintana Roo, Mexico ( $\mathrm{A}=$ Cancun, Mexico; $\mathrm{B}=$ Puerto Morelos, Mexico; C = Playa Del Carmen, Mexico) 


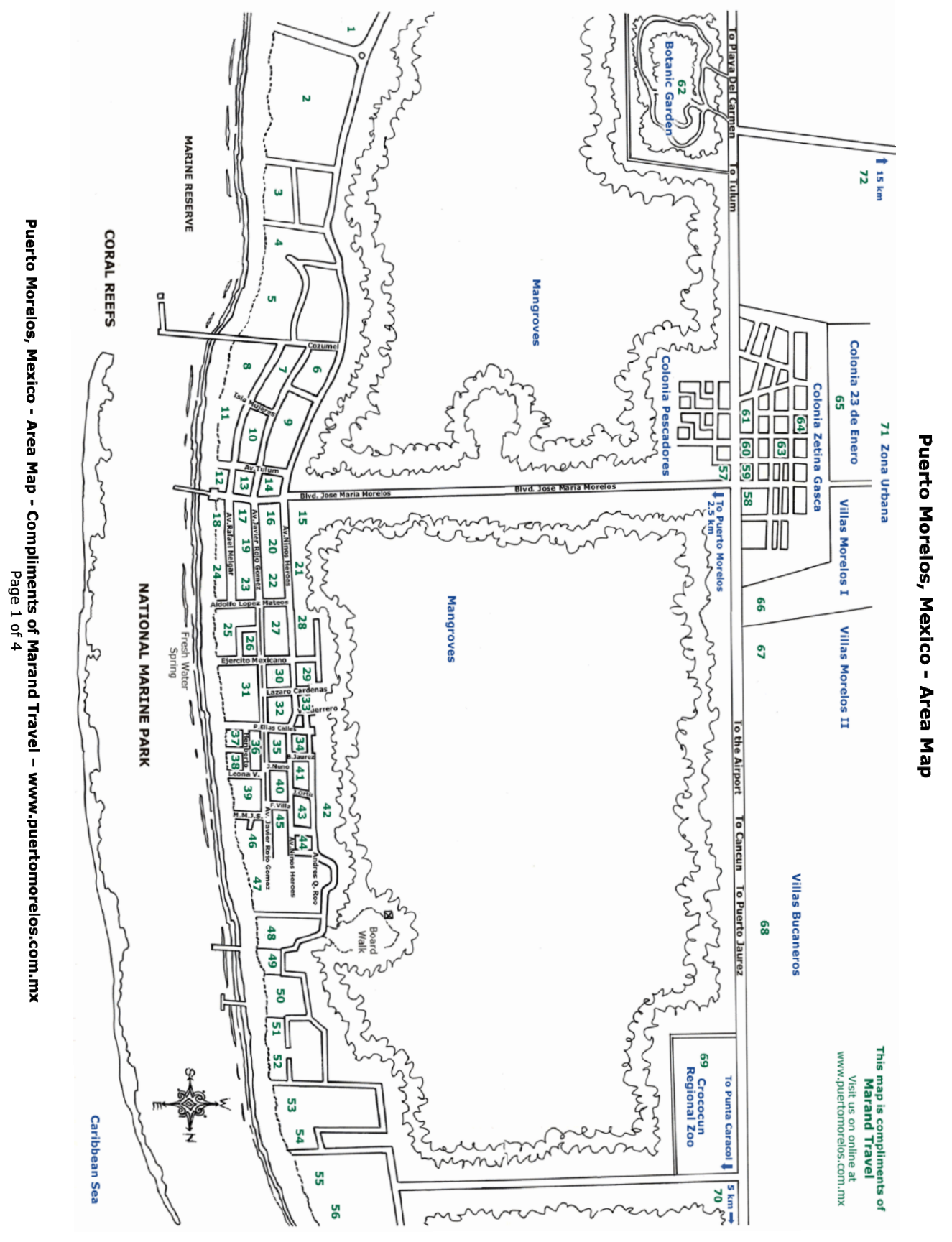

Figure 5. Two Major Sub Regions of Puerto Morelos, Mexico: La Playa \& La Colonia 


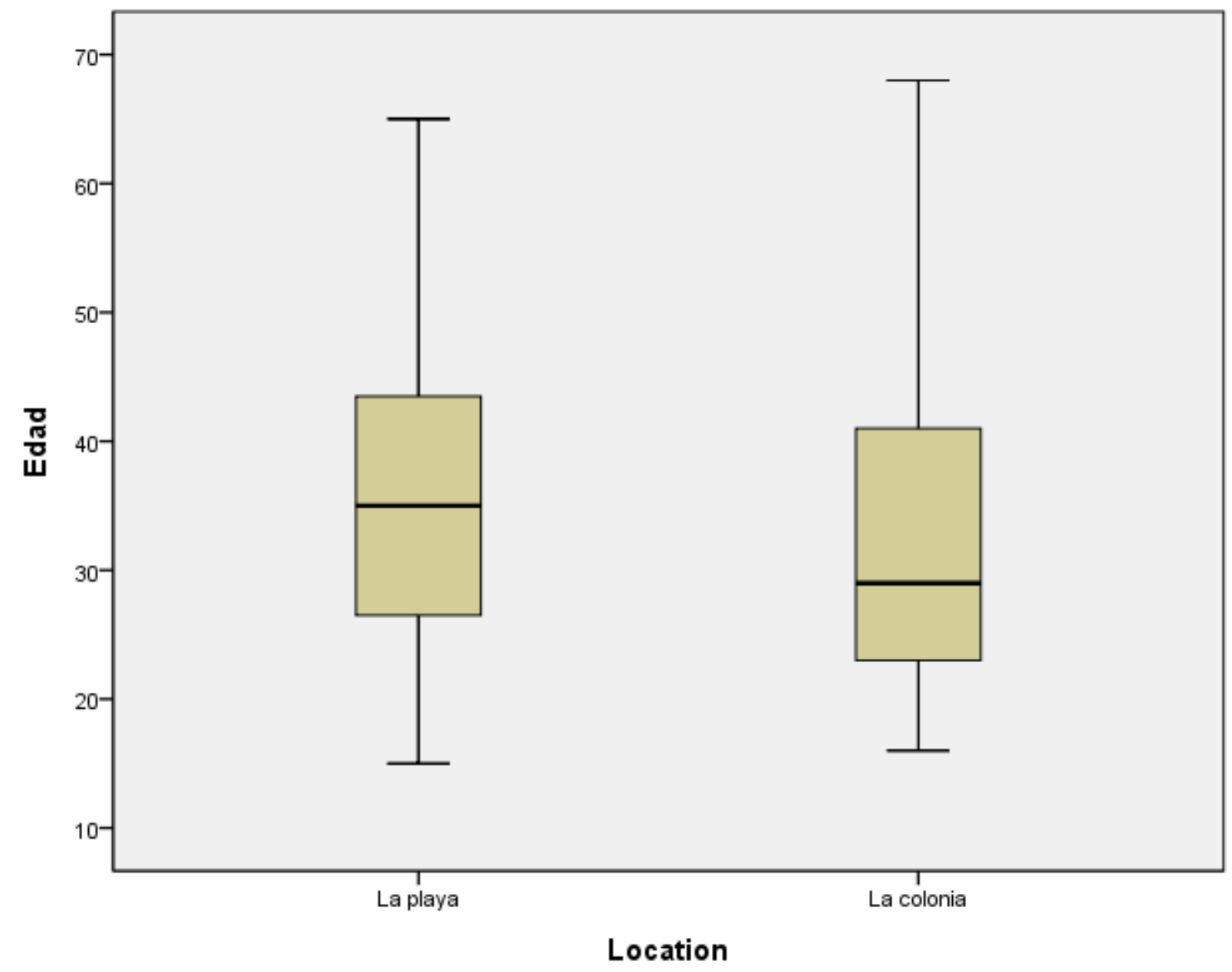

Figure 6. Average Age Of Participants Based Upon Location Of Residence 

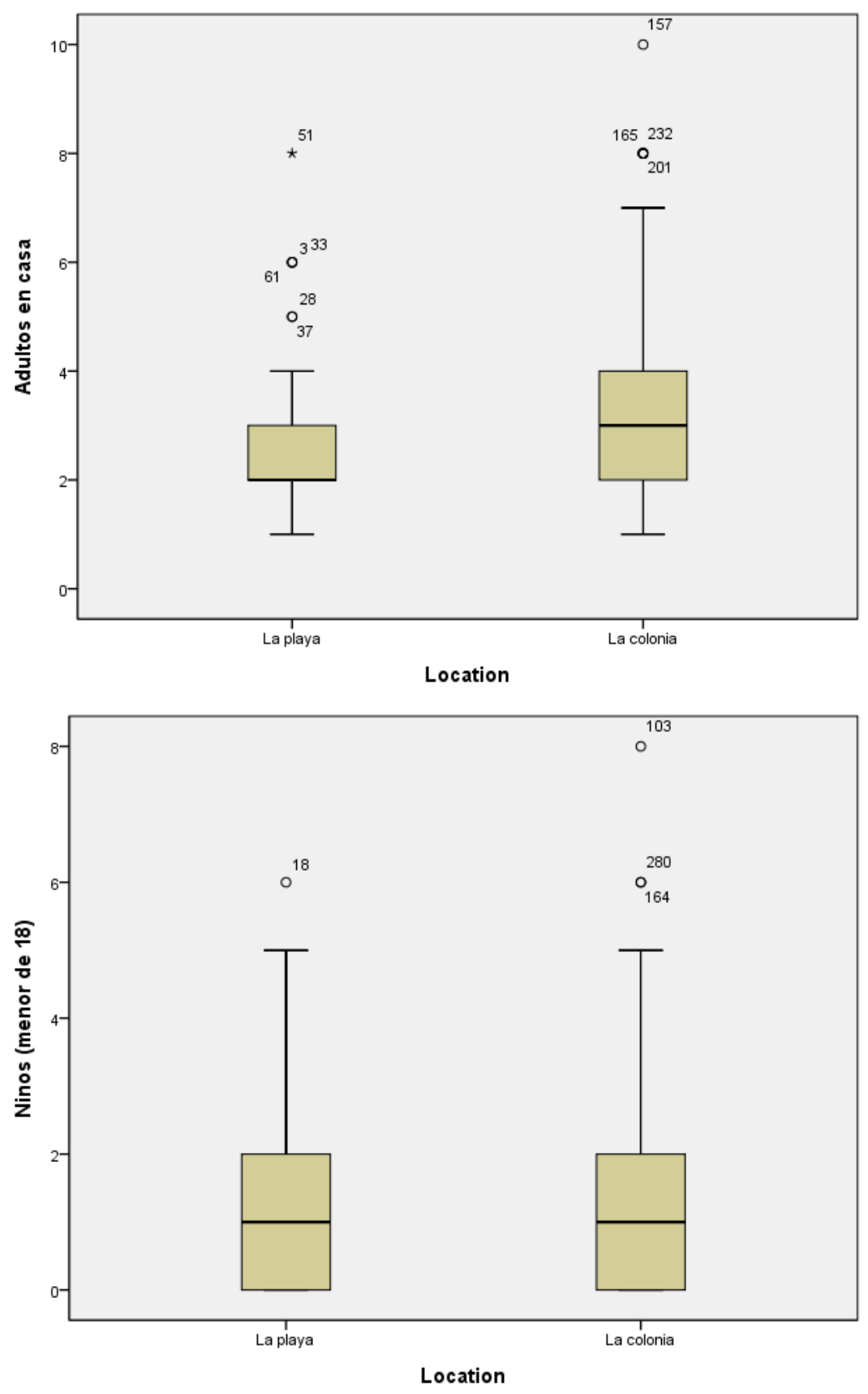


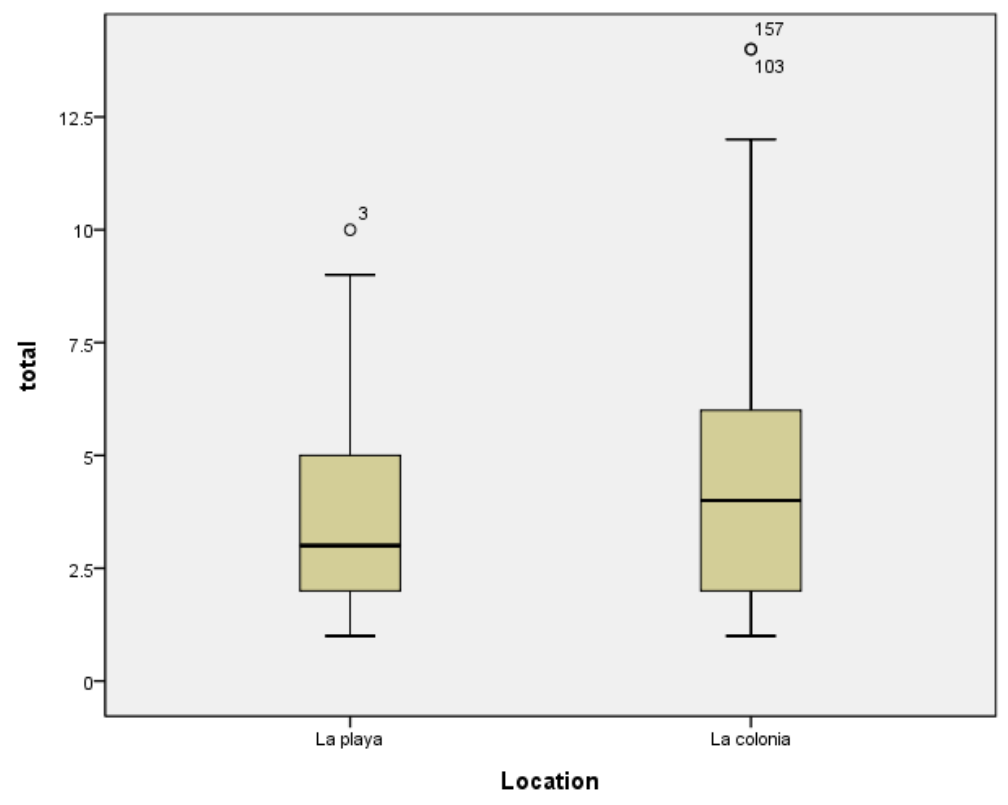

Figure 7. Average Number Of Adults \& Minors In The Household And The Average Total Number Of Individuals In A Household Based Upon Location Of Residence 


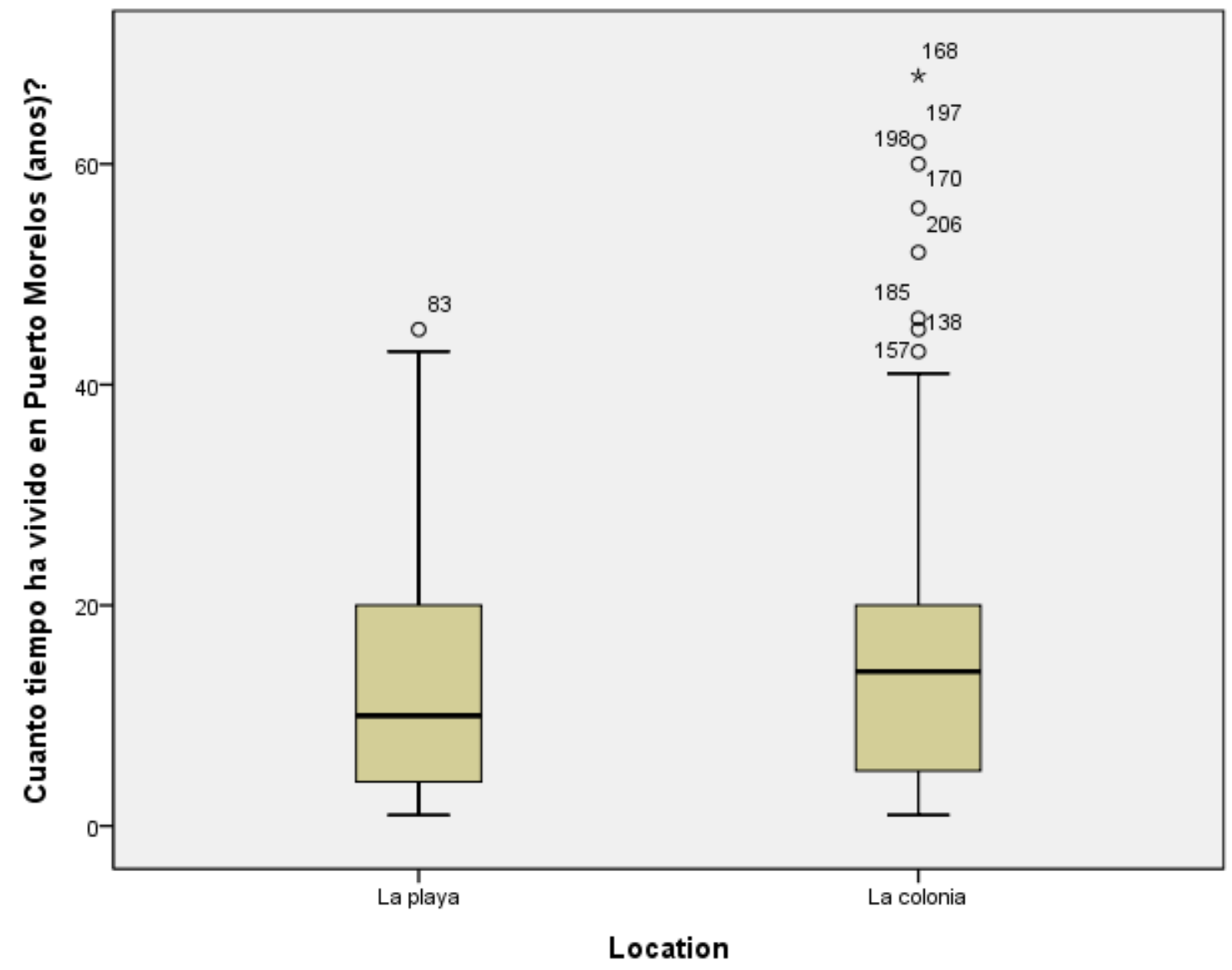

Figure 8. Average Time (years) Head of Household has lived in Puerto Morelos, Mx. Based upon Location of Residence 


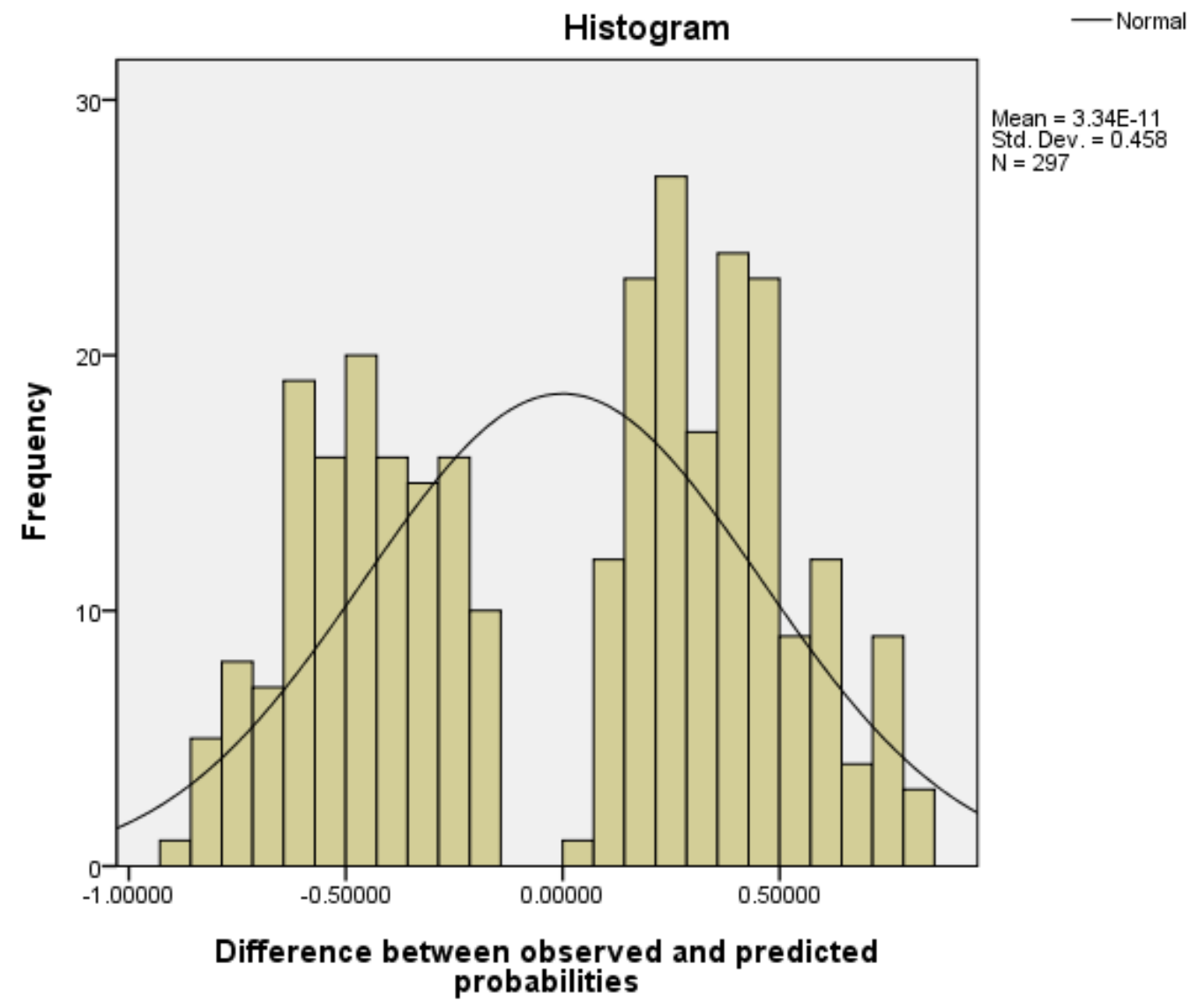

Figure 9. Normal Distribution for the Logistic Regression Analysis of the Variable SUPPORTESTABLSHMENT (Kolmogorov-Smirnov $=.141, \mathrm{df}=297, \mathrm{sig}=.000$; Shapiro-Wilk $=.932, \mathrm{df}=297, \mathrm{sig}=.000)$ 


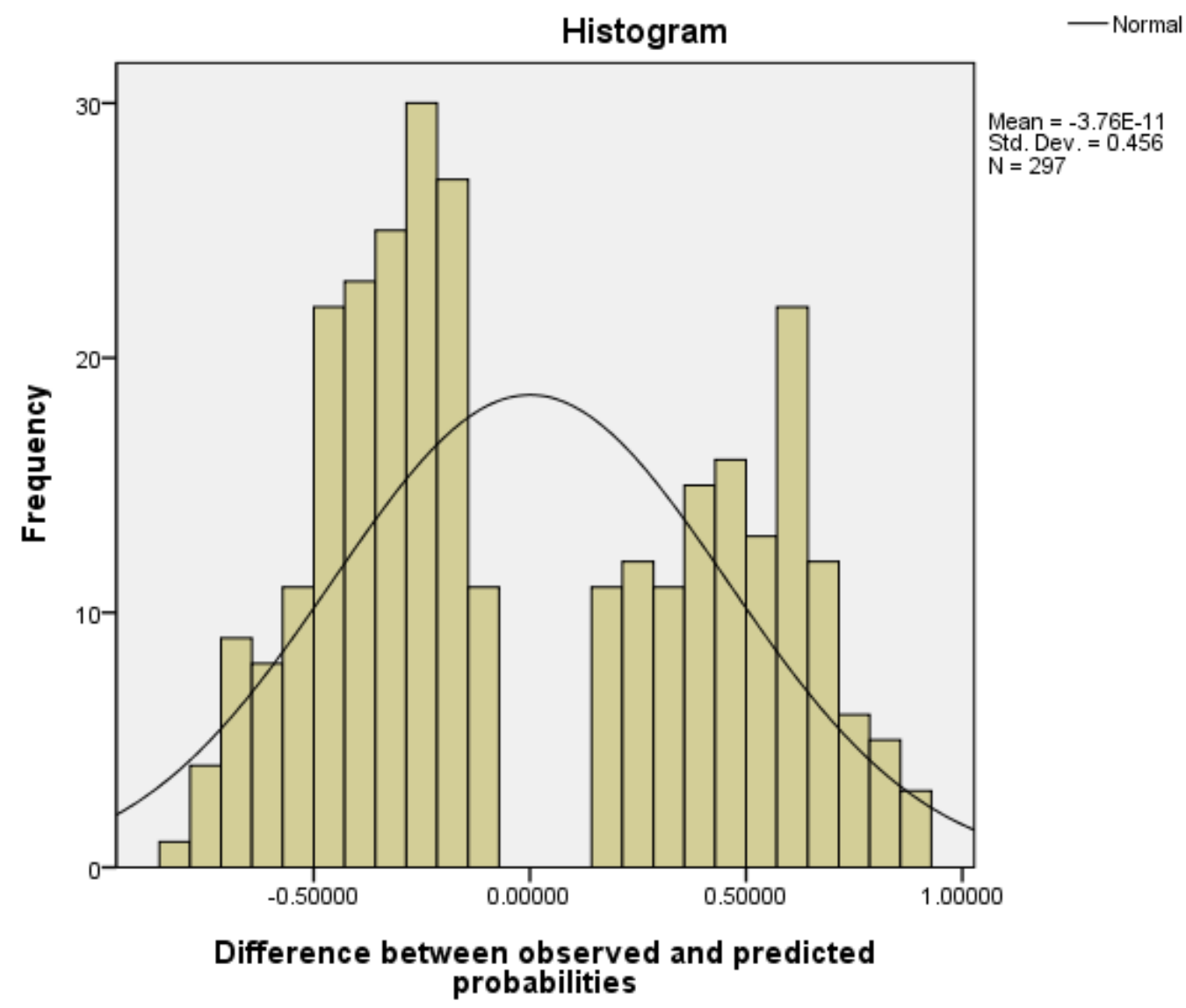

Figure 10. Normal Distribution for the Logistic Regression Analysis of the Variable INFAVOR (Kolmogorov-Smirnov $=.164, \mathrm{df}=297, \mathrm{sig}=.000$; Shapiro-Wilk $=.922, \mathrm{df}$ $=297, \mathrm{sig}=.000)$ 


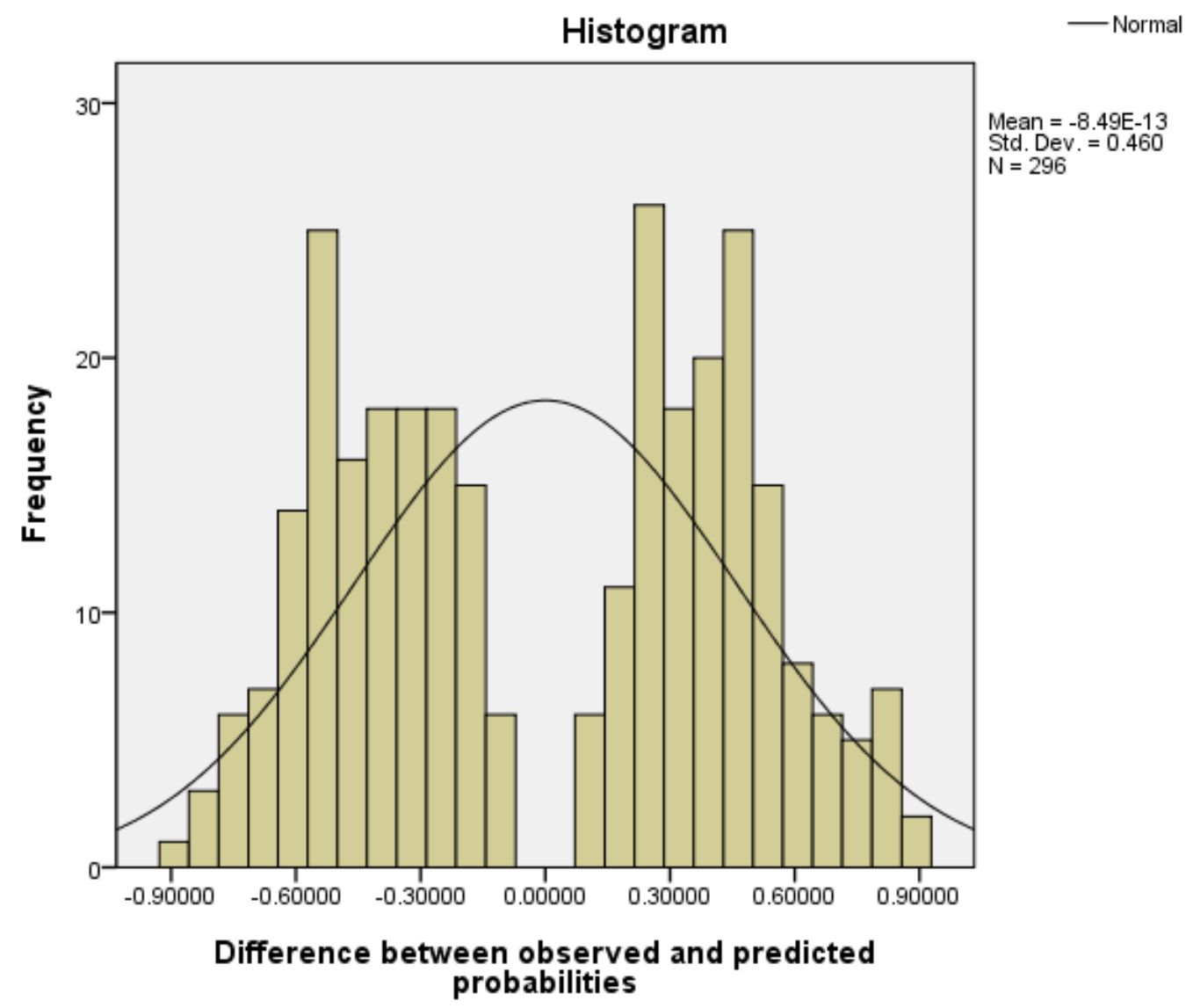

Figure 11. Normal Distribution for the Logistic Regression Analysis of the Variable OVERALL (Kolmogorov-Smirnov $=.135, \mathrm{df}=296, \mathrm{sig}=.000$; Shapiro-Wilk $=.932, \mathrm{df}$ $=296, \mathrm{sig}=.000)$ 